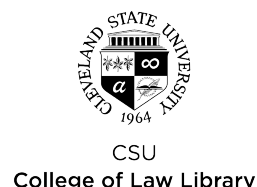

Cleveland State University

College of Law Library

\title{
EngagedScholarship@CSU
}

\section{Three Lies and a Truth: Adjudicating Maternity in Surrogacy Disputes}

Browne C. Lewis

Cleveland State University, blewis39@nccu.edu

Follow this and additional works at: https://engagedscholarship.csuohio.edu/fac_articles

Part of the Family Law Commons, and the Juvenile Law Commons

How does access to this work benefit you? Let us know!

Original Citation

Browne C. Lewis, Three Lies and a Truth: Adjudicating Maternity in Surrogacy Disputes, 49 University of Louisville Law Review 371 (2011)

This Article is brought to you for free and open access by the Faculty Scholarship at EngagedScholarship@CSU. It has been accepted for inclusion in Law Faculty Articles and Essays by an authorized administrator of EngagedScholarship@CSU. For more information, please contact research.services@law.csuohio.edu. 


\section{HEINONLINE}

Citation: 49 U. Louisville L. Rev. 371 2010-2011

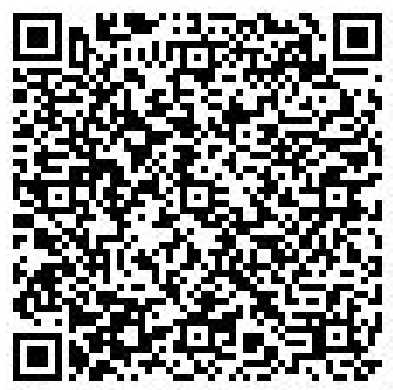

Content downloaded/printed from

HeinOnline (http://heinonline.org)

Fri May 2 14:03:46 2014

-- Your use of this HeinOnline PDF indicates your acceptance of HeinOnline's Terms and Conditions of the license agreement available at http://heinonline.org/HOL/License

-- The search text of this PDF is generated from uncorrected OCR text.

-- To obtain permission to use this article beyond the scope of your HeinOnline license, please use:

https://www.copyright.com/ccc/basicSearch.do?

\&operation $=$ go\&search $\mathrm{Type}=0$

\&lastSearch $=$ simple\&all=on\&titleOrStdNo $=1531-0183$ 


\title{
THREE LIES AND A TRUTH: ADJUDICATING MATERNITY IN SURROGACY DISPUTES
}

\author{
Browne C. Lewis
}

\section{TABLE OF CONTENTS}

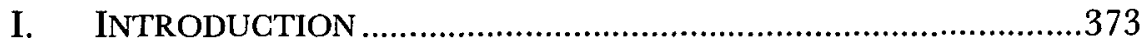

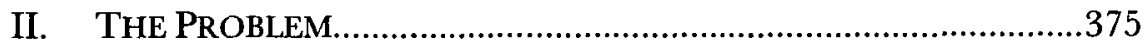

A. The Gestator (Gestational Surrogate)..................................................375

B. The Procreator (Traditional Surrogate)................................................377

III. LEGISLATING MATERNITY ………………………....................378

IV. IDENTIFYING THE LIES ..........................................................380

A. First There Was the Fallacy .........................................................381

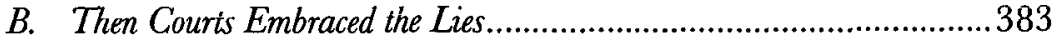

1. The Legal Mother Is the Woman Who Supplies the Genetic Material Used To Conceive the Child. 383

2. The Legal Mother Is the Woman Who Signs the Contract with the Intent of Parenting the Child.

3. The Legal Mother Is the Woman Who Gives Birth to the Ghild. 389

V. GETTING TO THE TRUTH …………..........................................392

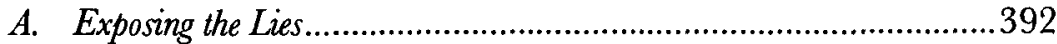

1. Blood Is Not Always Best.....................................................392

2. Believing Should Not Make It So ....................................397

3. Bonds Are Meant To Be Broken ........................................398

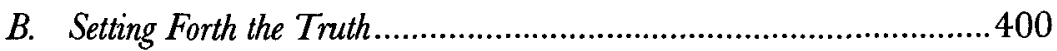

1. Sexual Intercourse …………………….............................401

a. The Evolution ................................................................... 401

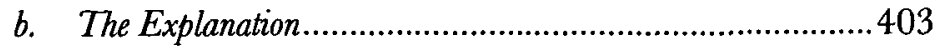




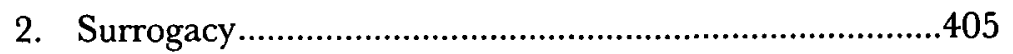

a. Arguing for the "Best Interests of the Child" Test................ 406

b. Applying the "Best Interests of the Child" Test ................... 408

i. Parental Potential ...........................................409

ii. Stability ...................................................... 410

iii. Primary Caretaker.........................................410

iv. Fairness ............................................................. 41

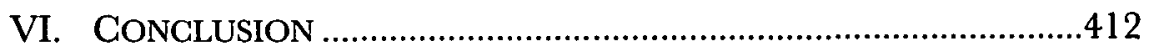




\title{
THREE LIES AND A TRUTH: ADJUDICATING MATERNITY IN SURROGACY DISPUTES
}

\author{
Browne C. Lewis
}

Three Lies:

(1) The legal mother of the child is the woman who supplies the genetic material for the child's conception.

(2) The legal mother of the child is the woman who contracts to have the child conceived with the intent to act as the parent.

(3) The legal mother of the child is the woman who gives birth to the child.

A Truth:

Maternity should be awarded based upon a determination of which mother-child relationship will best serve the child's interests.

\section{INTRODUCTION}

Historically, courts were called on to answer the following question: What makes a man a legal father? Courts applied different presumptions to arrive at the answer. For example, if the case involved a married couple, the woman's husband was presumed to be the legal father. ${ }^{1}$ In situations involving an unmarried woman, the man who helped to conceive the child was the legal father. ${ }^{2}$ While paternity was being litigated, maternity was resolved - the woman who gave birth to the child was the child's legal mother. ${ }^{3}$ The phrase "momma's baby, papa's maybe" reflected society's attitude towards maternity. ${ }^{4}$ Since the woman who gave birth to the child

- Associate Professor \& Director, Center for Health Law \& Policy, Cleveland-Marshall College of Law, Cleveland State University; B.A., Grambling State University, M.P.A, Hubert Humphrey Institute of Public Affairs; J.D., University of Minnesota School of Law, L.L.M., Energy \& Environmental Law, Univensity of Houston College of Law. I would like to thank Dean Phyllis Crocker and the Cleveland Marshall fund for supporting my research. I would also like to thank Professor Robin Wilson and the participants in the William \& Mary Junior Faculty Workshop for their comments on the article. Special thanks to my scholarship support group: Professors Heidi Robertson, Alan Weinstein and Kristina Niedringhaus.

1 Theresa Glennon, Someboty's Child. The Erosion of the Marital Pressomption of Patermity, 102 W. VA. L. REV. 547, $550(2000)$

${ }^{2}$ See Browne Lewis, Children of Mer: Balancing the Inheritance Rights of Marital and Non-Marital Chaldren, $39 \mathrm{U}$. TOL. L REV. 1, 9-11 (2007).

${ }^{3}$ Janet L Dolgin, fust a Gene: Zudicial Assomptions About Parenthood, 40 UCLA L. REv. 637, 672-73 (1993).

+ David M. Buss, Exobution and Human Mating, 18 HARV.J.L \& PUB. POL'Y 537, 543-44 (1995). 
also supplied the genetic material that created the child, maternity was not usually challenged. ${ }^{5}$ Hence, the courts did not have a hard time adjudicating maternity. Advances in reproductive technology have led to a change in the legal landscape. Consequently, two different women may claim to be the legal mother of the same child. ${ }^{6}$ As usual, the law has been slow to respond to the advances in medicine. ${ }^{7}$

Currently, with regard to children conceived using assisted reproduction, paternity is well-settled and maternity is debatable. In most jurisdictions, the man who consents to his wife being artificially inseminated using donor sperm is the legal father of the resulting child. ${ }^{8}$ Moreover, in the majority of states, a sperm donor is not recognized as the artificially conceived child's legal father. ${ }^{9}$ The use and availability of reproductive technology has made maternity more complicated. Courts do not have a bright-line rule to apply in order to determine maternity. The uniformity that exists among jurisdictions with regard to paternity cases involving artificially conceived children is lacking in maternity cases involving two women who want to be declared the legal mother of the child. ${ }^{10}$ Consequently, courts are forced to adjudicate the maternity of women involved in surrogacy arrangements in a piecemeal fashion. In making maternity determinations, courts have bought into the lie that the crucial factor is the reproductive rights of the women involved in the process. Based upon that lie, courts have applied several different standards to determine legal maternity. Some courts have ignored the one truth that has been consistent in different areas of family law: the "best interests of the child" standard is the appropriate one to use when making decisions that impact children. ${ }^{11}$

This Article is divided into four main Parts. Part II introduces the problem. Part III contains a discussion of the limited role legislatures have played in clarifying the legal status of the women involved in the surrogacy

\footnotetext{
${ }^{5}$ See id.

${ }^{6}$ See Alice Hofheimer, Note, Gestational Siongacy: Unsettling Slate Parentage Lav and Sionogacy Potigy, 19 N.Y.U. REV. L \& SOC. CHANGE 571, 571 (1992). (1998).

' See Janet L. Dolgin, An Energing Consensus: Reprochactive Tectrology and the Law, 23 VT. L REV. 225, 234

${ }^{8}$ Browne Lewis, Two Fathers, One Dad. Allocating Patemal Obbigations Between the Men Imolved in the Artifical Insemination Process, 13 LEWIS \& CLARK L. REV. 949, 959 (2009).

${ }^{9}$ Id. at 973.

${ }^{10}$ Ses, eg., In re Marriage of Burzanca, 72 Cal. Rptr. 2d 280 (Cal. Ct. App. 1998); In re Marriage of Moschetta, 30 Cal. Rptr. 2d 893 (Cal. Ct. App. 1994); see also Jonathan B. Pitt, Case Note, Frogmenting Procreation, 108 YALE LJ. 1893, 1893 (1999).

"Bridgette A Carr, Incorparating a "Beat Interests of the Crild" Approarh into Immigration Lave and Procechere, 12 YALE HUM. RTS. \& DEV. LJ. 120, 124 (2009).
} 
process. Part IV analyzes the tests or standards courts have employed to determine maternity in surrogacy cases. Part V explains the reasons why the best interests of the child standard is the one that courts should apply to determine the legal mother of the child conceived as the result of a surrogacy agreement. ${ }^{12}$

\section{THE PROBLEM}

\section{A. The Gestator (Gestational Surrogate) ${ }^{13}$}

While studying drama at Yale, actors Angela Bassett and Courtney Vance met and fell in love with each other. ${ }^{14}$ More than a decade later, the couple got married. The couple enjoyed a successful marriage and acting careers. ${ }^{15}$ Nonetheless, there was something missing in their lives. After years of infertility, Ms. Bassett and Mr. Vance had an embryo created using her eggs and his sperm implanted into a surrogate. The surrogate gave birth to the couple's twins. ${ }^{16}$ Although the surrogate gestated the twins, she did not have a biological connection to them. As in most surrogate arrangements, the surrogate relinquished her parental rights and surrendered the child to the couple. If the surrogate decided not to relinquish her rights to the children, should she have standing to fight for custody of the children?

Married couple Ikufumi and Yuki Yamada desperately wanted a child. Since the couple could not conceive naturally, they signed a surrogacy agreement with Dr. Nanya Patel. ${ }^{17}$ Presumably under the terms of the agreement, after the child was born, the surrogate promised to give up her parental rights so that the Yamadas could adopt the baby. ${ }^{18}$ Prior to the

${ }^{12}$ Scholars like Ilana Hurwitz have advocated for adopting the best interests of the child standard to make parenthood determination in surrogacy cases. See, e.g., llana Hurwitz, Collaborative Reproctuction: Finting the Child in the Maze of Legal Motherhood, 33 CONN. L REv. 127, 169-74 (2000). Others have criticized the use of the standard to adjudicate maternity. See, eg., Rene R. Gilliam, Note, When $A$ Sturogate Mother Breaks a Promise: The Inappropriateness of the Traditional "Best Interests of the Crild" Standard, 18 MEMPHIS ST. U. L REV. 514, 527-32 (1988). I differ from those persons in the manner in which I think the court should apply the standand.

13 A gestational surrogate has been defined as "the woman who gives birth to a child regardless of her genetic relationship to the child." VA. CODE ANN. § 20-156 (West, Westlaw through 2010 Reg. Sess.).

${ }^{14}$ Angela Bassett and Coutngy B. Vance, OPRAH.COM (Mar. 5, 2007), www.oprah.com/oprahradio/AngelaBassett-and-Courtney-B-Vance.

${ }^{15}$ See id; Stcphen M. Silverman, Twins for Angela Bassett \& Coromey Vance, PeOPLE.coM (Jan. 30, 2006, 10:00 PM), htp://www.people.com/people/article/0,1154648,00.html.

${ }^{16}$ See Silverman, supra note 15.

17 Usha R. Smerdon, Crossing Bodies, Crossing Borders: Intemational Sirrogacy Between the Umited States and India, 39 GUMB. L REV. 15, 69 (2008).

${ }^{18}$ For a discussion of the operation of Dr. Patel's surrogacy clinic, see id. at 48-50. 
birth of the child, the Yamadas divorced. ${ }^{19}$ Consequently, Ms. Yamada decided that she did not want to adopt the child. ${ }^{20}$ Despite Ms. Yamada's decision, the surrogate relinquished her parental rights.21 Therefore the child was legally motherless. Mr. Yamada still wanted to adopt the child, but Indian law prohibited a single man from adopting. ${ }^{22}$ As a result, the child was left in a legal limbo. ${ }^{23}$ Should the contracting woman be adjudicated the legal mother and forced to adopt the child? Should the surrogate who gave birth to the child be prevented from abandoning the child?

As the above examples illustrate, the surrogacy process enables a woman who is unable to carry a child to become a mother. Under the surrogacy arrangement, one woman agrees to assist another woman in having a child. The type of assistance the surrogate provides varies. For example, the surrogate's role may be limited to that of a gestator or carrier. Gestational surrogacy involves the implantation of an embryo into the uterus of the woman acting as the surrogate. ${ }^{24}$ If the contracting woman is capable of producing eggs but is unable to carry a child, her eggs are fertilized with her husband's sperm to create the embryo that is implanted in the woman serving as a surrogate. ${ }^{25}$ On the other hand, if the woman is incapable of producing eggs and cannot carry a child, a donor's eggs are united with the sperm of the woman's husband in order to create the embryo gestated by the surrogate. ${ }^{26}$ In either case, the gestational surrogate $^{27}$ is not biologically related to the child. ${ }^{28}$ However, that fact has not prevented litigation over whether or not the gestational surrogate has parental rights.

${ }^{19}$ Id. at 70 .

${ }^{20} \mathrm{Id}$

2) See Japanese Girl Bom to Indian Strrogate Arrives Home, CNN.com (Nov. 2, 2008), http://www.cnn.com/ 2008/WORLD/asiapcf/11/02/indiababy/index.html?iref=allsearch (" $[N]$ either the birth mother nor the mother who had originally sought the child wanted to be involved.").

22 Id

${ }^{23}$ See id.

${ }^{24}$ Jamie L. Zuckerman, Comment, Extreme Makecuer-Siarogacy Edition: Reassessing the Marriage Requiranent in Gestational Surnogacy Contracts and the Right To Ravoke Consent in Traditional Sturogacy Agreements, 32 NOVA L. REV. 661, 663-64 (2008) (discussing the different types of gestational surrogacy arrangements).

${ }^{25}$ Ronald Chester, To Be, Be, Be. . . Not fust To Be: Legal and Social Implications of Cloning for Human Refmoduction, 49 FLA. L. REV. 303, 331 (1997).

${ }^{26}$ Lori B. Andrews \& Lisa Douglass, Altemative Reproduction, 65 S. CAL. L. REV. 623, 631 (1991).

27 "Gestational surrogate" is often defined as a woman who agrees to conceive a child using reproductive technology without utilizing her own eggs. See, eg., FLA. STAT. ANN. § 742.13(5) West, Westlaw through Chap. 274 (End) of the $20102 \mathrm{~d}$ Reg. Sess. of the $21 \mathrm{st} \mathrm{Leg}$.).

${ }^{28}$ Bemard Friedland \& Valerie Epps, The Changing Famity and the U.S. Immigration Law: The Impact of Metical Reproductive Tathnology on the Immigration and Nationality Act's Definition of the Famib, 11 GEO. IMMIGR. LJ. 429, 454 (1997). 


\section{B. The Procreator (Traditional Surrogate) ${ }^{29}$}

After Michael Jackson died, his mother, Katherine Jackson, filed a petition seeking custody of Michael Jackson's three young children. ${ }^{30}$ Ms. Jackson's petition stated that the children had no relationship with their biological mothers. ${ }^{31}$ Debbie Rowe was listed as the mother of Jackson's two older children. ${ }^{32}$ With regard to "Blanket," Jackson's youngest child, the petition presumably listed the mother as "None." 33 According to Jackson's will, in the event that his mother is unable to care for the children, Diana Ross should be permitted to raise the three children. ${ }^{34}$ The probate court complied with Mr. Jackson's wishes and appointed Ms. Jackson as the children's permanent legal guardian. ${ }^{35}$ The court also gave Ms. Rowe liberal visitation with the two older children. ${ }^{36}$ When Michael Jackson died on June 24, 2009, Blanket and his two siblings became fatherless. However, unlike his siblings, Blanket was born legally motherless. ${ }^{37}$ Thus, Blanket is a legal orphan. Blanket's legal status makes him more vulnerable than his siblings. If both Ms. Jackson and Ms. Ross predeceased Mr. Jackson, since Ms. Rowe's parental rights were not terminated, she is the legal mother of the two older children. ${ }^{38}$ That status gives Ms. Rowe the opportunity to parent those children. If she could be identified, should Blanket's biological mother be given the same opportunity?

An Israeli couple was devastated when a Palestinian sniper killed their son, Keivan, in August 2002.39 Instead of grieving, the couple was

${ }^{29}$ A traditional surrogate is a woman who both contributes a gamete to create the child and gives birth to the child. See Jennifer L. Watson, Growing a Baby for Sale or Mereby Renting a Womb: Should Surrogate Mothers Be Compensated for Their Senvices?, 6 WHITTERJ. CHID \& FAM. ADVOC. 529, 529 (2007).

${ }^{30}$ Steve Helling \& Champ Clark, Joe and Katherine Jackson Want Thase Chaldren, PEOPLE.COM (June 29, 2009, 12:50 PM), http://www.people.com/people/package/article/0,20287787_20288314,00html.

${ }^{31}$ Id.

32 Id.

33 See Katherine Jackson Naned Children's Guartion, MSNBC.COM, htt://today.msnbc.msn.com/id/ 32270692/ns/today-entertainment/ (last updated Aug. 3, 2009) (noting that "Blanket" was born through a surrogate with no parental rights).

${ }^{34}$ See Luchina Fisher et al, Michael Jackson's Lave for Diana Rass Continues Even in Death, ABC NEws (July 2, 2009), http://abcnews.go.com/Entertainment/MichaelJackson/story?id=7984854\&page=1.

35 Alan Duke, Deal Reached For Custady of Michael Jackson's Children, CNN.com July 30, 2009), http://articles.cnn.com/2009-07-30/entertainment/jackson.children.custody_1_katherine-jackson-debbie-rowems-jackson?_s=PM:SHOWBIZ.

${ }^{36}$ See id

37 See Katherine Jackson Named Crildren's Guartian, supra note 33 (noting that the surrogate that carried "Blanket" had no parental rights).

38 See generally Count Voids Debbie Rouve's Lass of Rights to Jacko's Kids, FOXNEWS.COM (Feb. 16, 2006), http://www.foxnews.com/story/0,2933,185083,00.html.

39 Family of Dead Lstaeti Soldier Can Use His Sperm, MSNBC.COM Jan. 29, 2007), htp://www.msnbc.msn.com/id/16871062/; also Ruth Zafran, Dying To Be A Father. Logal Patemity in Case of 
proactive. They decided to create a grandchild to rear. A doctor extracted sperm from Keivan's body. ${ }^{40}$ Then, the couple hired a surrogate to contribute genetic material and give birth to their grandchild. ${ }^{41}$ Baby Doe was born legally motherless to a woman who never knew his father. ${ }^{42}$ If the surrogate decided that she wanted to keep the child instead of giving it to the grandparents, should she be permitted to do so? In the event something happens to the elderly couple, should the surrogate be permitted to take custody of the child?

The second type of surrogacy arrangement involves a traditional surrogate. A traditional surrogate is a woman who is artificially inseminated with the sperm of the contracting woman's husband or significant other..$^{43}$ Since her eggs are used to create the child, the traditional surrogate is biologically related to the child. ${ }^{44}$ As a consequence, traditional surrogacy agreements usually contain provisions requiring the surrogate to terminate her parental rights and allowing the contracting woman to adopt the child..$^{45}$ As in any contract dispute, courts do not become involved until one or more of the parties to the contract decide not to abide by the terms of the contract. In a surrogacy situation, the legal dispute usually arises when the surrogate refuses to surrender the child to the intended parent or parents. The courts are called upon to identify the legal parents of the child..$^{46}$

\section{LEGISLATING MATERNITY}

It is important that the parent-child relationship ${ }^{47}$ be legally recognized because the existence of that relationship impacts so many aspects of the child's life. For example, in order for the child to have the right to receive financial support from an adult, the person seeking the support must show that a legal parent-child relationship exists. The recognition of that

\footnotetext{
Posthomous Conception, 8 HOUS.J. HEALTH L. \& POL'Y 47, 54 n.22 (2007).

${ }^{40}$ Farrily of Dead Israeti Soldier Can Use His Sperm, supra note 39.

${ }^{41}$ See id.

${ }^{2}$ See Zafran, supra note 39, at 54.

${ }^{43}$ Steven H. Snyder \& Mary P. Bym, The Use of Prebirth Parentage Orders in Sionogacy Proceedings, 39 FAM. L.Q. 633,639 (2005).

4 Emily Stark, Comment, Bom to No Mother. In re Roberto D.B. and Equal Protection for Gestational Sumogate Rebutting Matemity, 16 AM. U.J. GENDER SOC. POL'Y \& L 283, 287 (2007).

${ }^{5}$ See Sherrie L. Russell-Browne, Parental Rights and Gestational Starogacy: An Aggument Against the Genetic Standard, 23 Colum. HuM. RTS. L REv. 525, 527 (1992); see also Kermit Roosevelt III, The Navest Property: Reproductive Technologies and the Concopt of Parenthood, 39 SANTA CLARA L. REV. 79, 125 (1998).

${ }^{46}$ Seg, eg., J.F. v. D.B., 897 A.2d 1261 (Pa. Super. C. 2006).

${ }^{47}$ CAL. FAM. CODE $\$ 7601$ (West, Westlaw through 2009 Reg. Sess.; all 2009-2010 1st through 5th, 7th, and 8th Exec. Sess.; urgency legis. through Ch. 301 of the 2010 Reg. Sess.; and all Props. on 2010 ballots) ("Parent and child relationship'... means the legal relationship existing between a child and the child's natural or adoptive parents incident to which the law confers or imposes rights, privileges, duties, and obligations. The term indudes the mother and child relationship and the father and child relationship.").
} 
relationship also affects the child's ability to inherit from his or her parents and to receive certain government benefits. ${ }^{48}$ Parents benefit from the establishment of the relationship because it gives them the legal right to make important decisions with regard to the child. ${ }^{49}$ In addition, the existence of a legal parent-child relationship prevents the government and others from terminating the person's parental rights and removing the child from his or her care without cause. ${ }^{50}$

Most state statutes do not establish a mechanism for creating the mother-child relationship in the context of a surrogacy arrangement. The state statutes that do address the maternity issue do so in several ways. Some state statutes indicate that birth is the key indicator of motherhood. ${ }^{51}$ However, legal maternity may be reallocated by a valid surrogacy contract. ${ }^{52}$ Other statutes emphasize intent, ${ }^{53}$ still others emphasize gestation, ${ }^{54}$ as the factor that should be used to determine which woman should be recognized as the child's legal mother. In states that permit surrogacy contracts to be enforced, the terms of the contract may control the allocation of maternity. ${ }^{55}$ Thus, the intended mother is usually found to be the legal mother if the contract complies with the mandates of the statute and is approved by the court. ${ }^{56}$ If the contract is invalid, ${ }^{57}$ or unenforceable

48 Richard L. Brown, Disinheriting the "Legal Opphan": Inheritance Rights of Children After Termination of Parental Rights, 70 MO. L. REV. 125, 144-45 (2005).

49 See Erin E. Bybee, Case Note, Family Law-Parental Rights-Protection of Parntal Rights in Custody and Temination of Parental Rights Cases in Tennessee, 75 TENN. L. REV. 151, 155-56 (2007).

${ }^{50}$ Richard L. Brown, Undeserving Heirs? - The Case of the "Teminated" Parent, 40 U. RICH. L. ReV. 547, 549 (2006).

${ }^{51}$ Seg, eg., ARK. CODE ANN. § 9-10-201(b), (c)(1) (West, Westlaw through end of 2010 Fiscal Sess., induding changes made by Ark. Code Rev. Comm. received through July 1, 2010); see also N.D. CENT. CODE ANN. $\$ 30.1-04-19(6)$ (West, Westlaw through 2009 Reg. Sess.) (providing that the woman who gives birth, unless she is a gestational surrogate, is the child's legal mother).

${ }^{52}$ See, eg., WASH. REV. CODE ANN. \$26.26.101(1)(d) (West, Westlaw through 2010 Legis. effective through Jan. 1, 2011).

53 See, e.g., TEX. FaM. CODE ANN. $\$ 160.760$ (West, Westlaw through end of the 2009 Reg. and 1st Called Sess. of the 81 st Leg.).

54 See, eg., VA. CODE ANN. § 20-158(A)(1) (West, Westlaw through end of 2010 Reg. Sess.) ("The gestational mother of a child is the child's mother."). But see Soos v. Superior Court, 897 P.2d 1356, 1361 (Ariz. C. App. 1994) (holding that statute naming gestational surrogate the legal mother without giving the biological mother who donated the eggs the opportunity to prove maturity violates the equal protection clause).

55 Seg, eg., VA. CODE ANN. $§ 20-159(B)$.

56 See id $\S 20-159$ (A) ("A surrogate, her husband, if any, and prospective intended parents may enter into a written agreement whereby the surrogate may relinquish all her rights and duties as parent of a child conceived through assisted conception, and the intended parents may become the parents of the child ....").

${ }^{57}$ Several states have statutes setting forth the process for having a surrogacy arrangement validated. Sef eg., N.H. REV. STAT. ANN. § 168-B:23 (Westlaw through laws currently effective Sept. 10, 2010 through Ch. 381 of the 2010 Reg. Sess. and Ch. 1 of the Special Sess.); TEX. FAM. CODE ANN. $\S 160.755$ (West, Westlaw through end of the 2009 Reg. and Ist Called Sess. of the 81st Leg.). 
for some reason, the surrogate is typically recognized as the child's legal mother. ${ }^{58}$

Some jurisdictions treat surrogacy arrangements similar to adoptions..$^{59}$ As a result, the surrogate is given a specific period of time after the birth of the child to give notice of her intent to keep the child.60 Once that notice is given, the court designates the surrogate as the legal mother of the child. ${ }^{61}$ Some states only permit pure gestational surrogate arrangements where the surrogate is not allowed to use her own eggs. In those jurisdictions, the gestational surrogate is not recognized as the child's legal mother. ${ }^{62}$ Thus, gestation is not the standard used to determine maternity. ${ }^{63}$ Finally, if there is a dispute between the intended mother and the surrogate over custody of the child, in some jurisdictions, the court will assign maternity based upon what it considers to be the best interests of the child. ${ }^{64}$ The lack of legislation in this area has led to custody disputes between the surrogate and the contracting couple.

\section{IDENTIFYING THE LIES}

In states where the statutes do not enumerate the factors to be used to identify the legal mother of a child born as the result of a surrogacy arrangement, courts have to determine which woman is the child's legal mother. There is no uniform test for allocating maternity in those cases. Thus, courts have adopted several different tests to determine the identity of the legal mother of the child. The cases in this Part illustrate the application of those tests. Prior to analyzing those cases, it is helpful to discuss the first case in which a court seemed to slowly embrace the lie that maternity should be determined based upon the actions or status of the women involved in the process.

58 See, eg., N.D. CENT. CODE ANN. § 14-18-05 (West, Westlaw through 2009 Reg. Sess.); see also VA. CODE ANN. $\S 20-158(\mathrm{D})$.

${ }_{59}$ See, eg., A.H.W. v. G.H.B., 772 A.2d 948 (NJ. Super. Ct. Ch. Div. 2000).

${ }^{60}$ N.H. REV. STAT. ANN. § 168-B:25(IV).

${ }^{61}$ Id.

62 See 750 IL. COMP. STAT. ANN. 45/6(a)(1)(A) (West, Westlaw through P.A. 96-1382 of the 2010 Reg. Sess. 2010); TeX. FAM. CODE ANN. § 160.754(a)(2); UTAH CODE ANN. § 78B-15-801(1) (West, Westlaw through 2010 Gen. Sess).

63 See 750 IL COMP. STAT. ANN. 45/6(a)(1)(A); TEX. FAM. CODE ANN. § 160.754(a)(2); UTAH CODE ANN. $§ 78 \mathrm{~B}-15-801(1)$.

${ }_{64}$ Ses, eg., MrCH. COMP. LAWS ANN. $\$ 722.861$ (West, Westlaw through P.A. 2010, No. 217, of the 2010 Reg. Sess., 95th Leg.). 


\section{A. First There Was the Fallacy}

\section{In the Matter of Baby $M^{65}$}

The first major case involving a surrogacy custody dispute was Baby $M .{ }^{66}$ The case brought the maternity issue to the attention of the general public. The court had the difficult task of determining which woman involved in the process should be designated as the child's legal mother. The case involved a surrogacy contract signed by William Stern and Mary Beth Whitehead.67 Under the terms of the contract, Ms. Whitehead agreed to be artificially inseminated with Mr. Stern's sperm. ${ }^{68}$ Based on the contract, after the child's birth, Ms. Whitehead was required to take steps to terminate her parental rights. ${ }^{69}$ Ms. Stern planned to adopt the child. ${ }^{70}$ Ms. Stern was not a party to the surrogacy agreement, but the contract gave her sole custody of the child if Mr. Stern died. ${ }^{71} \mathrm{Mr}$. Stern agreed to pay Ms. Whitehead $\$ 10,000$ after she turned the child over to him. ${ }^{72}$ "In a separate contract, Mr. Stern agreed to pay $\$ 7,500$ to the Infertility Center of New York" to compensate the Center for its part in the procedure. ${ }^{73}$

When the baby was born, Ms. Whitehead did not want to give the baby to the Sterns. ${ }^{74}$ During her pregnancy, Ms. Whitehead developed a bond with the child. ${ }^{75}$ However, Ms. Whitehead eventually turned the child over to the Sterns. ${ }^{76}$ Later, Ms. Whitehead fell into a deep depression. ${ }^{77}$ Ms. Whitehead went to the Sterns' home and told them that she could not live without her baby. ${ }^{78}$ The Sterns felt sorry for Ms. Whitehead because they were afraid she planned to hurt herself. ${ }^{79}$ Hence, they agreed to let her keep the baby for a week. ${ }^{80} \mathrm{Ms}$. Whitehead promised to return the child to

\footnotetext{
${ }^{65}$ In re Baby M, 537 A.2d 1227 (N.J. 1988).

${ }^{66}$ For a general discussion of Baby $M$, see Vicki C. Jackson, Baby M and the Question Of Parenthood, 76 GEO. LJ. 1811 (1988).

${ }^{67}$ In re Baby $M, 537$ A.2d at 1235.

${ }^{6 \rightarrow} I d$.

${ }^{69}$ See id.

${ }^{70} \mathrm{Id}$.

${ }^{7} I d$.

${ }^{72} \mathrm{Id}$

${ }^{73} \mathrm{Id}$

${ }^{74}$ See id at 1236.

${ }^{75} \mathrm{Id}$

${ }^{76}$ Id

77 Id

${ }^{78}$ Id at $1236-37$.

${ }^{79}$ See id at 1237.

${ }^{80} \mathrm{Sex}$ id.
} 
the Sterns at the end of the specified period. ${ }^{81}$ Ms. Whitehead did not keep her promise, so the authorities had to forcibly remove the baby from her. ${ }^{82}$

The Sterns sued to enforce the surrogacy contract. ${ }^{83}$ They asked the court to order Ms. Whitehead to comply with the terms of the contract. ${ }^{84}$ Specifically, the Sterns wanted the court to terminate Ms. Whitehead's parental rights and to place the child in their custody permanently. ${ }^{85}$ In addition, they asked the court to give Ms. Stern permission to adopt the child. ${ }^{86}$

The court had to decide whether the surrogacy contract was valid. ${ }^{87}$ In response, the court voided the agreement because it was against the public policy of the state. ${ }^{88}$ According to the court, it was illegal to compensate a woman for acting as a surrogate. ${ }^{89}$ The court opined that the practice had the potential to be degrading to women..$^{90}$ Once it invalidated the contract, the court awarded custody based upon genetics and the best interests of the child. ${ }^{11}$ As the biological father, Mr. Stern received custody of the child because the court found that arrangement to be in the child's best interests. ${ }^{92}$ However, based on her biological connection to the child, the court adjudicated Ms. Whitehead to be the child's legal mother. ${ }^{93}$ That status entitled Ms. Whitehead to visitation rights. ${ }^{94}$ Thus, the case was remanded, so the lower court could address that issue. ${ }^{95} \mathrm{Ms}$. Whitehead did not have to terminate her parental rights, and Ms. Stern did not get the right to adopt the child. In its opinion, the court indicated that a surrogacy agreement might be enforceable if an uncompensated woman voluntarily agreed to act as a surrogate. ${ }^{96}$ However, the court noted that, in order to be enforceable, the contract could not contain a provision requiring the woman to give up custody of her child. ${ }^{97}$

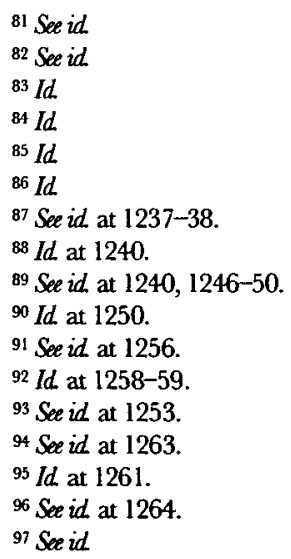


In the $B a b y M$ case, it is clear that the court meant for biology to be the sole indicator of maternity. The court determined maternity by comparing the actions of the women involved in the process. Ms. Whitehead was actively involved in the process because she contributed the genetic material used to conceive the child and she gestated the child. For practical purposes, there was no difference between Ms. Whitehead and a woman who conceived a child through sexual intercourse. Thus, the court's decision to adjudicate Ms. Whitehead as the legal mother did not cause much public outrage. The court viewed Ms. Stern as a passive participant who did not make any contributions to the child's conception. Ms. Stern was treated like a potential adoptive mother. As a stranger to the child, she did not have any maternal rights. In reaching its decision, the court weighed the reproductive rights of each woman.

The best interests of the child standard was used to determine which of the legal parents should receive physical custody of the child. In keeping with past precedents, the court did not use the best interests of the child standard to make the initial parentage decision. ${ }^{98}$ By ignoring the interests of the child, the court perpetuated the lie that the fitness of the adults to raise the child is not relevant when it comes to adjudicating parentage. Throughout the opinion, the court treated the traditional surrogate as the legal mother of the child. ${ }^{99}$ Consequently, the court never raised the issue of Ms. Stern's maternal right. The court seemed to assume that, since she did not supply the genetic material to create the child, Ms. Stern should not be recognized as the child's legal mother even if it would be in the child's best interests to do so. As the cases in the next section illustrate, several courts have challenged that assumption by relying on other lies.

\section{B. Then Courts Embraced the Lies}

\section{The Legal Mother Is the Woman Who Supplies the Genetic Material} Used To Conceive the Child.

In most contexts, courts have relied upon genetics to designate parentage. For example, paternity tests are utilized to ensure that the man recognized as the child's legal father is biologically related to the child. ${ }^{100}$ Furthermore, in order to lose custody or be denied visitation, the biological

\footnotetext{
98 See id. at 1243.

${ }^{99}$ See, eg., id at 1240 .

100 See Niccol D. Konding, Litlle White Lies that Destroy Children's Lives-Recteating Patemity Fraud Laws To Protext Children's Interests, 6J.L. \& FAM. STUD. 237, 252 (2004).
} 
parent must be found unfit. ${ }^{101}$ Society places a high value on blood relations. The law reflects that respect for blood connections by granting preference to blood relatives in several contexts. For instance, a biological parent must give consent before his or her child can be legally adopted. This is true even in cases where the biological parent has no relationship with the child.102 In addition, as a consequence of the fascination with blood ties, in most jurisdictions, stepchildren are not permitted to inherit from stepparents under the intestacy system (unless the children have been adopted). ${ }^{103}$ The reasoning behind that exclusion is that a person would want preference given to his or her biological children.104 It is not surprising that some courts think that biology should be the main indicator of parentage. In particular, those courts have indicated that the test for maternity is genetics. The following case demonstrates that prevarication.

\section{Belsito v. Clark ${ }^{105}$}

A diagnosis of cervical cancer caused Shelly Belsito to lose her uterus. ${ }^{106}$ However, the doctor left Shelly's ovaries intact, and she was able to produce eggs. ${ }^{107}$ When Shelly and Anthony Belsito got married, they agreed that they wanted to have children. ${ }^{108}$ Carol S. Clark, Shelly's sister, agreed to act as a surrogate for the couple. ${ }^{109}$ Two of the embryos that were created by fertilizing Shelly's eggs with Anthony's sperm were implanted in Carol's uterus. ${ }^{110}$ A couple of weeks later, a test confirmed Carol was pregnant with a child conceived from one of Shelly and Anthony's embryos. ${ }^{111}$

When she was getting ready for the impending birth of the child, Shelly spoke with the hospital personnel about the child's birth certificate. ${ }^{112}$ At that time, they told her that, since Carol was giving birth to the child, Carol,

\footnotetext{
101 Sez Suzette M. Haynie, Biological Parents v. Third Parties: Whase Right to Child Custady is Constitutionally Protected?, 20 GA. L. REV. 705, 708 (1986).

102 Ses eg., Gary Debele, Custady and Parenting By Passons Other than Biological Parents Whon Non-Traditional Famity Law Collides with the Constitution, 83 N.D. L REV. 1227, 1236 (2007).

${ }^{103}$ See Margaret M. Mahoney, Stepparents as Third Paties in Relation to Their Sicpctildtren, 40 FAM. LQ. 81, 98 (2006); Andrew L. Noble, Intestate Succession for Stepchildren in Pennyluamia A Propasal for Reform, 64 U. PTTT. L. REV. 835,840 (2003).

104 See Mahoney, supra note 103, at 99.

${ }^{105}$ Belsito v. Clark, 644 N.E.2d 760 (Ohio Ct. Com. P. 1994). For an analysis of Belsito, see Dawn Wenk, Note, Betsito v Clark: Ohio's Battle with "Motherhood", 28 U. TOL. L REv. 247 (1996).

${ }^{106}$ Belsito, 644 N.E.2d at 761 .

${ }^{107} \mathrm{Id}$

${ }_{108}$ Se id at 760-61.

${ }^{109} \mathrm{Id}$ at 761.

110 Id

${ }^{111} / d$.

$112 \mathrm{Id}$ at 762.
} 
not Shelly, would be listed on the birth certificate as the child's legal mother. ${ }^{113}$ Shelly also learned that the child would be considered illegitimate because the legal parents, Carol and Anthony, were not married to each other. ${ }^{114}$ In response, Shelly and Anthony went to court seeking a declaration that, since they were the child's legal parents, they did not need to adopt the child. ${ }^{115}$ They also asked for a court order mandating that the child be listed as legitimate on the birth certificate and that they be listed as the legal parents on the birth certificate. ${ }^{116}$

The court had to decide whom to designate as the child's legal and natural parents. In order to make that determination, the court had to decide what makes a person a natural parent. ${ }^{117}$ After reviewing the case law, the court concluded that, in order for a person to be deemed a natural parent, the person had to be connected to the child by blood. ${ }^{118}$ That blood connection was established by proof that the person and the child were genetically connected by DNA. ${ }^{119}$ The court opined that "the test to identify the natural parents should be, 'Who are the genetic parents?"'120

The court put forth several reasons why it adopted the genetic test. First, the court contended that a genetic test was more consistent with the public policy of not permitting a woman to sell her parental rights. ${ }^{121}$ The court reasoned that, since she did not provide the genetic material used to create the child, the surrogate was not the child's natural mother. ${ }^{122}$ Thus, whenever the surrogate surrendered the child, she would not be exchanging her parental rights for a monetary payment. In that case, the surrogate would simply be fulfilling the terms of the contract. Second, the court concluded that the genetic test would be easy to apply. Any dispute with regard to the identity of the natural mother could be easily resolved through DNA testing. ${ }^{123}$

According to the court, the identification of the natural parent might not be the end of the inquiry. ${ }^{124} \mathrm{~A}$ surrogate who did not contribute genetic

\footnotetext{
$113 \mathrm{Id}$

${ }^{115} I d$

116 Id.

117 See id.

$118 \mathrm{Id}$

119 Id at 763 .

${ }^{120}$ Id. at 766 .

121 See it.

${ }^{122}$ Id.

${ }^{123}$ Id at $766-67$.

${ }^{124}$ Id at 767 .
} 
material to create the child is not the child's natural mother. Nonetheless, that woman might be classified as the child's legal mother. ${ }^{125}$ In order to become the child's legal mother, the surrogate had to follow the dictates of the state's adoption laws. ${ }^{126}$ In this case, the court did not fully address the steps necessary for a gestational surrogate to be recognized as the child's legal mother because Carol did not assert her maternal rights. ${ }^{127}$

The court held that Anthony and Shelly were the child's natural parents because they contributed the genetic materials used to conceive the child. ${ }^{128}$ Moreover, the court ruled that, since Anthony and Shelly did not relinquish or waive their parental rights, they were the child's legal parents. ${ }^{129}$ In sum, the court decided that the genetic mother is always the natural mother of the child. The natural mother is also the child's legal mother unless she takes steps to terminate her maternal rights so that another woman can be designated the legal mother. ${ }^{130}$ The court made it clear that the woman who contributed the genetic material to create the child had superior rights over the woman who gave birth to the child. ${ }^{131}$ The court adopted the genetics test to determine maternity in a surrogacy arrangement.

The court attempted to treat a child conceived as the result of a surrogacy arrangement similar to a child conceived by sexual intercourse. If a man uses his penis to fertilize a woman's eggs with his sperm, she is clearly the child's natural mother. Under the standard set out in Belsito, the outcome would not be different just because the child was conceived using scientific means. Thus, if a doctor fertilizes a woman's eggs with a man's sperm and inserts the embryo into another woman's body, the woman who supplied the eggs does not lose her biological connection to the child. A woman who conceives a child naturally can sever her connection to the child and put the child up for adoption, so that another woman can become the child's legal mother. The reasoning of the Belsito case indicates that the same option is available to a woman who contributes the genetic material in a surrogacy arrangement. That woman can voluntarily relinquish her right to the child, so that the surrogate or another woman can become the child's legal mother. In either case, the law cannot force the woman to turn her

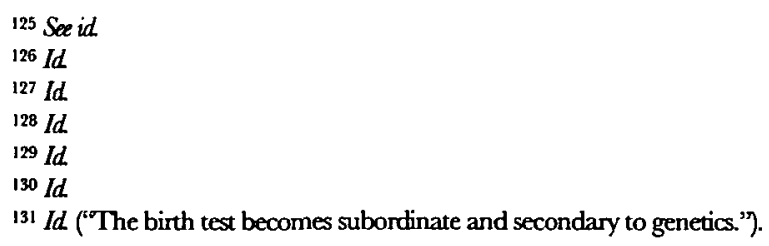


biological child over to another woman. However, some courts assert that intentions should outweigh genetics.

2. The Legal Mother Is the Woman Who Signs the Contract with the Intent of Parenting the Child.

According to Professor Shultz, courts should adjudicate legal parenthood by considering the parties' intentions. ${ }^{132}$ In particular, Professor Shultz contends, "intentions that are voluntarily chosen, deliberate, express and bargained-for ought presumptively to determine legal parenthood."133 Some courts have applied this logic to conclude that evaluating the parties' intent should be the method used to resolve custody disputes between surrogates and contracting couples. The next case demonstrates reliance on that falsehood.

\section{Johnson v. Calvert ${ }^{134}$ (Majority Opinion)}

Mark and Crispina Calvert's plans to become parents were thwarted when Crispina had to have a hystercctomy. ${ }^{135}$ Nonetheless, since Crispina was still capable of producing eggs, the couple decided to arrange for a surrogate to carry their child. ${ }^{136}$ Anna Johnson agreed to act as a surrogate for the couple. ${ }^{137}$ The parties signed a surrogacy agreement. ${ }^{138}$ Under the terms of the agreement, Anna would carry a child conceived using an embryo created from Mark's sperm and Crispina's eggs. ${ }^{139}$ After the birth of the child, Anna promised to relinquish her parental rights to the child and to surrender the child to the Calverts. ${ }^{140}$ In exchange, Mark and Crispina agreed to pay Anna $\$ 10,000$ and to insure Anna's life for $\$ 200,000.141$ The $\$ 10,000$ was scheduled to be paid in installments. ${ }^{142}$ After Anna became pregnant with the couple's child, relations between the parties soured. ${ }^{143}$ Eventually, Anna demanded that the Calverts pay the

132 Marjorie M. Shulz, Reproductize Technology and Intent-Based Parenthood: An Opportaraity for Gender Neutratity, 1990 WIS. L. REV. 297, 302.

133 Id. at 323.

${ }^{134}$ Johnson v. Calvert, 851 P.2d 776 (Cal. 1993).

${ }_{135}$ See id. at 778 .

${ }^{136} I d$

${ }^{137} I d$.

${ }^{138} I d$

${ }^{139}$ Id.

${ }^{140} I d$

${ }^{141} I d$.

${ }^{142} I d$.

143 See id 
remainder of the payments she was owed. 144 Anna threatened to keep the child if she did not receive all of the money. ${ }^{145}$ In response, the Calverts filed a lawsuit to be legally recognized as the parents of the unborn child. ${ }^{146}$ Then, Anna brought an action requesting to be declared the child's legal mother. ${ }^{147}$ The court consolidated the cases. ${ }^{148}$

Blood tests showed that the Calverts were the child's genetic parents. ${ }^{149}$ The court had to decide the identity of the child's natural mother under California law. The trial court held that the Calverts were the child's "genetic, biological and natural" parents and Anna had no parental rights with regard to the child. ${ }^{150}$ After the court of appeals affirmed the trial court's decision, Anna filed an appeal with the California Supreme Court. 151

The supreme court relied on the Uniform Parentage Act (UPA) to resolve the dispute. 152 Anna based her claim to the child on the fact that she gestated and gave birth to the child. ${ }^{153}$ The Calverts countered by arguing that since the child was conceived using her genetic material, Crispina was the child's legal mother. ${ }^{154}$ When allocating maternity, the court had to decide whether to give preference to the woman having the blood connection to the child or the woman giving birth to the child. The court decided that both women were able to produce evidence of a mother-child relationship under the provisions of the statute. ${ }^{155}$ According to one section of the UPA, maternity could be proven by the use of genetic evidence gathered through blood testing. ${ }^{156}$ Since the blood tests indicated that Crispina was the child's genetic mother, she could satisfy the evidentiary requirements of the statute. ${ }^{157}$ Another portion of the statute stated that a woman could establish the mother-child relationship by showing she gave birth to the child. ${ }^{158}$ In the case at bar, Anna was able to prove that fact. ${ }^{159}$

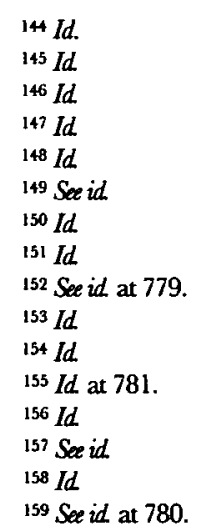


Both women satisfied the statutory mandates to prove maternity, so the child appeared to have two natural mothers. However, the State of California would only recognize one legal mother. ${ }^{160}$

The court relied upon contract principles to resolve the case. To that end, the court analyzed the terms of the surrogacy agreement. ${ }^{161}$ The court held that the appropriate test for determining the identity of the legal mother of the child was the "intent" test. ${ }^{162}$ Specifically, the court stated "she who intended to procreate the child-that is, she who intended to bring about the birth of a child that she intended to raise as her own-is the natural mother under California law."163 The Calverts intended to have a child from their genetic material. They carried out that intent by having an embryo, created using his sperm and her egg, implanted in Anna. Anna agreed to assist the Calverts in carrying out their intentions. The child would not exist if the Calverts had not acted on their intentions. The court found that Anna's intent to keep the child should not be recognized because it conflicts with the original intentions of the parties. ${ }^{164}$ The court seems to indicate that the existence of a traditional surrogacy arrangement would not have changed the outcome of the case. The key factor in determining maternity was intent and not genetics. According to some courts, intent and genetics should take a back seat to gestation.

\section{The Legal Mother Is the Woman Who Gives Birth to the Child.}

A woman who gestates a child forms a special bond with that child. That connection grows from the moment of implantation of the embryo until the birth of the child. For forty weeks, that woman nurtures and cares for the child. 165 Some commentators have argued that this "sweat equity" should transform the surrogate from a gestator to a cultivator. ${ }^{166}$ That classification of the surrogate's role acknowledges that the surrogate contributes something of herself to the child. Consequently, she should be regarded as more than a womb or an incubator. ${ }^{167}$ The surrogate role as a

${ }^{160}$ Id. at 781. This is consistent with the state's treatment of patemity. See Michael H. v. Gerald D., 491 U.S. 110,118 (1989) (stating that Califomia law does not permit a child to have two legal fathers).

${ }^{161}$ Jahmsom, 851 P.2d at 782.

162 See id.

${ }^{163} \mathrm{Id}$

${ }^{16+}$ Id.

${ }^{165}$ See Lawrence O. Gostin, Sumogacy from the Perspectives of Economic and Curil Liberties, 17 CONTEMP. HEALTH L. \& POL'Y 429, 435 (2001).

166 See, e.g., Scott B. Rae, Parental Rights and the Defuition of Mathothood in Storngate Mothathood, 3 S. CAL. REV. L. \& WOMEN'S STUD. 219, 236 (1994).

167 See Gostin, supra note 165, at 435. 
gestator should factor into the determination of maternity. That untruth is put forth by the court in the next case.

\section{A.H.W. v. G.H.B. ${ }^{168}$}

Gina, an unmarried woman, agreed to serve as a surrogate for her sister, Andrea, and Andrea's husband, Peter. ${ }^{169}$ Consequently, an embryo created using Peter's sperm and Andrea's eggs was implanted into Gina's uterus. ${ }^{170}$ Gina was not paid for her services. ${ }^{171}$ Gina became pregnant as a result of the implantation. ${ }^{172}$ Approximately two weeks before Gina was scheduled to give birth, Peter and Andrea petitioned the court for an order declaring the maternity and paternity of the unborn child. ${ }^{173}$ Specifically, the couple asked the court to issue a prebirth order adjudicating them as the child's legal parents and requiring that their names be listed on the child's birth certificate. ${ }^{174}$

In support of their petition, the biological parents argued that because Gina, the gestational surrogate, did not have a biological connection to the child, she should not be recognized as having any parental rights with regard to the child. ${ }^{175}$ Gina supported the couple's argument. ${ }^{176}$ Moreover, Peter, Andrea, and Gina claimed that Gina was nothing more than an incubator. ${ }^{177}$ The court took issue with that classification of a gestational surrogate. ${ }^{178}$ According to the court, Gina did more than incubate the child. To support its contention, the court described the bond between a child and the gestational mother. ${ }^{179}$ The court referred to Gina as a gestational mother instead of a gestational surrogate. ${ }^{180}$ The court felt that title was more appropriate because of the contributions that the gestating woman made to the child's well-being during the pregnancy. ${ }^{181}$

${ }_{168}^{168}$ A.W.W. v. G.H.B., 772 A.2d 948 (N.J. 2000); see also J.F. v. D.B., 66 Pa. D \& C. 4th 1 (C.P. Ct. of Erie County 2004).

${ }^{169}$ A.H.W., 772 A.2d at 949.

${ }_{170} \mathrm{Id}$

${ }^{171}$ Id.

172 See id.

${ }^{173} I d$ at 950.

174 Id

175 Id at 953

${ }^{176}$ Id

${ }^{177} \mathrm{Id}$

${ }^{178} I d$.

$179 \mathrm{Id}$

$180 / d$.

${ }^{181}$ Id. 
Once the court decided that the gestational mother was the child's legal mother, the court refused to grant the prebirth order. ${ }^{182}$ After reviewing the state statutes and case law, including the Baby $M$ case, the court concluded that forcing Gina to surrender her parental rights prior to the birth of the child was contrary to New Jersey law. 183 The court held that Gina could not surrender her parental rights until seventy-two hours after she gave birth. ${ }^{184}$ In New Jersey, the statute required a woman to wait seventy-two hours before consenting to the adoption of her child. 185 The court felt that the same waiting period was appropriate in a case involving a gestational surrogate because the woman would experience the same emotional and physical changes during birth as a woman who gave birth to her biological child. ${ }^{186}$ The court also opined that Gina had the option of changing her mind and filing an action to retain custody of the child. ${ }^{187}$

In reaching its decision, the court emphasized that a strong connection between the woman and the child formed during the pregnancy and at birth. ${ }^{188}$ That connection is not weakened by the lack of a biological link. The mother-child relationship develops because of the dependency of the child on the mother. The woman who supplies the eggs that result in the creation of the embryo has a connection to the embryo but not to the resulting child. The woman who provides the nutrients necessary for the embryo to develop into a child is the child's natural and legal mother. That woman is the woman who gestates the child. ${ }^{189}$ As a consequence, gestation is the controlling factor in adjudicating maternity.

Reproductive technology that makes surrogacy possible has resulted in two women having the potential to receive maternal rights. ${ }^{190}$ Thus, courts are faced with the daunting task of adjudicating legal maternity. With little legislative guidance, courts have embraced the lie that genetics, intent, or gestation makes a woman a legal mother. Each of those standards is flawed.

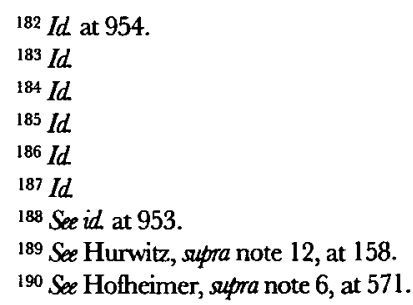




\section{GETTING TO THE TRUTH}

\section{A. Exposing the Lies}

In order to get to the truth, it is necessary to debunk the lies. The underlying premise of the lie is that courts should determine maternity by deciding which factors justify declaring a woman to be a legal mother. Should motherhood be based upon blood, belief, or bonding? Is the legal mother the woman who shared blood with the child, the woman who believed she would be the mother, or the woman who bonded with the child? The answer to this question is not dispositive because it is based upon the fabrication that maternity is about the woman and not the child. A critical evaluation of the genetics, intent, and gestation tests shows that not one of these tests gets the courts to their end goal - selecting the best legal mother for the child created as the result of a surrogacy agreement. Each of the tests used by courts to determine maternity has merit. Nonetheless, ultimate application of the tests does not consider the interests of the child. That crucial shortcoming negates the benefits of applying the tests. This section evaluates each test.

\section{Blood Is Not Always Best}

The genetics test highlights the idiom that "blood is thicker than water." That commonly used phrase indicates that bonds are stronger between persons who are related by blood. ${ }^{191}$ Despite the widespread acceptance of adoption, there is still a societal belief that, if possible, children should live with their blood relatives. As a result, utilizing the genetics test is a safe choice for a court from a public policy perspective. Furthermore, it is logical for a court to apply the genetics test because it is consistent with prior judicial treatment of these types of cases and lines up with the expectations of the general public. For instance, when a man supplies the genetic material used to create a child, he is usually given the opportunity to be recognized as the child's legal father. ${ }^{192}$ That step is taken to protect the man's reproductive rights. By classifying the woman who contributes the genetic material that results in the child's conception as the legal mother, the court is being consistent and fair. ${ }^{193}$ There is no good reason to treat women involved in assisted reproduction arrangements different from the

\footnotetext{
191 See Nicole L Sault, Mony Mothers, Many Fathers: The Meaning of Parenting Aromd the World, 36 SANTA Clara L REV. 395, 398-99 (1996).

192 See Snyder \& Bym, supra note 43 , at 639.

${ }^{193}$ See Hotheimer, supra note 6 , at 601 .
} 
men involved in similar situations. In addition, the selection of the genetics test encourages blood relatives to stay together. The average person would expect to rear a child who was conceived using his or her genetic material. The court is treating the mothers of children born as the result of surrogacy arrangements like the mothers of children conceived in other ways. For example, in order for a child to be taken from his or her biological mother, that woman must take affirmative steps to terminate her parental rights and consent to an adoption. ${ }^{194}$ Women who use reproductive technology to conceive should be given that same treatment.

Even with the advances in reproductive technology, a child cannot be created without the use of genetic material. ${ }^{195}$ According to John Locke, humans have ownership of themselves and, thus, they are entitled to benefit from the fruits of their labor. ${ }^{196}$ It follows that the person who contributes the genetic material should be given an ownership interest in the child conceived using that material. This is not an outrageous assertion because courts have recognized ownership interest in sperm. In Hecht v. Superior Court, the court held that a man had the right to leave his sperm to his girlfriend by will. ${ }^{197}$ A woman should have the same property interest in her eggs. ${ }^{198}$ The Moore v. Regents of the University of Califormia court held that a man did not have a property interest in his cells once they were removed from his body. 199 Nonetheless, the court determined that the man had the right to control his cells as long as they were in his body. ${ }^{200}$ Consequently, those cells could not be removed without his informed consent. ${ }^{201}$ Applying this reasoning to the genetic supplier of the eggs in a surrogacy situation, a woman has control over her eggs as long as they are inside her body. The eggs cannot be used unless the woman gives her informed consent. In a surrogacy situation, there should be a rebuttable presumption that the biological mother is only consenting to the use of her eggs to conceive a child she plans to parent. In the interest of fairness, the gestational

\footnotetext{
${ }^{194}$ See, eg., Shannon E. Phillips, Praxnting Bidding Wars in Washington Adoptions: The Need for Statutory Reform After In re Dependency of G.C.B., 70 WASH. L REV. 277, 279-80 (1995); Karen D. Laverdiere, Note, Content Over Fom: The Shifting of Adoption Consent Lows, 25 WHITTIER L REV. 599 (2004).

195 See In re C.K.G., 173 S.W.3d 714, 727 (Tenn. 2005).

${ }^{196}$ See Radhika Rao, Propory, Privag, and the Human Bady, 80 B.U. L. REV. 359, 367-68 (2000) (discussing the bocty as property and the influential theory of John Locke on the subject).

${ }^{197}$ Hecht v. Superior Court, 20 Cal. Rptr. 2d 275, 283 (Cal. Ct. App. 1993).

198 See Erik B. Seeney, Note, Moore 10 Years Later-Still Tying To Fill the Gap: Creating a Personal Property Right in Genetic Material, 32 NEW ENG. L. REV. 1131, 1170-71 (1998) (arguing for a recognition of a property right in genetic material).

${ }^{199}$ Moore v. Regents of Univ. of Cal., 793 P.2d 479, 493-94 (Cal. 1990).

200 Se id.

201 Id; see Roger F. Friedman, It's My Body and Pll Die if I Want Ta: A Propaty-Based Amument in Support of Assisted Siacide, 12 J. CONTEMP. HEALTH L. \& POL'Y 183, 208 (1995).
} 
surrogate should have the right to rebut this presumption by introducing evidence of a contrary intent.

The adoption of the genetics test is also consistent with prior legal precedents. In Dawis v. Davis, the court held that there is a fundamental right to procreate and a fundamental right not to procreate. ${ }^{202}$ This implies that a person has the ultimate control of his or her reproductive materials. In fact, in Dairs, the court concluded that a person has a constitutional right to control the disposition of his or her own genetic material. ${ }^{203}$ As the Belsito court indicated, the application of the genetics test is warranted from an evidentiary standpoint. ${ }^{204}$ DNA tests could be used to confirm that the genetic mother is the biological mother of the child. ${ }^{205}$ Moreover, the genetics test establishes a bright-line rule for determining maternity. ${ }^{206}$ Once DNA testing proves that the woman is the biological mother of the child, it is easy to recognize her as the legal mother of the child. ${ }^{207}$ This is important in situations where the facility mistakenly implants a woman with an embryo belonging to another couple. ${ }^{208}$ In essence, that woman becomes an involuntary surrogate. ${ }^{209}$ Since she did not supply the genetic material used to create the embryo, the woman should not have any expectations of keeping the child. Thus, she may not be likely to file a custody petition to keep the child. ${ }^{210}$ The certainty that she cannot be named the legal mother of the child may serve as a deterrent to the

${ }^{202}$ Davis v. Davis, 842 S.W.2d 588, 601 (Tenn. 1992); see also Christina C. Lawrence, Note, Procreative Liberty and the Areanbro Problem: Daxloping a Metical and Legal Framawork To Settle the Dispasition of Frozen Areembryos, 52 CASE W. RES. L. REV. 721, 737-38 (2002).

${ }^{203}$ Dauis, 842 S.W.2d at 602.

${ }^{204}$ See Belsito v. Clark, 644 N.E.2d 760, 766 (Ohio Ct. Com. P. 1994).

${ }^{205} \mathrm{See}$ Christine A. Bjorkman, Note, Sitting In Limbo: The Absence of Connecticut Regulation of Surogate Patenting Agreements and Its Effect on Parties to the Agrement, 21 QUINNIPIAC PROB. L.J. 141, 159 (2008) (discussing Johnson v. Catuert and use of DNA tests as evidence in proving matemity); Amy M. Larkey, Note, Redefuring Motherhood: Determining Legal Matemity in Gestational Semogary Amangements, 51 DRAKE L. REV. 605, 623 (2003) (discussing Johnson v. Cabert and use of DNA tests as evidence in proving maternity). (2006).

${ }_{206}$ Melanie B. Jacobs, My Two Dads: Disaggregating Biological and Social Patemity, 38 ARIZ. ST. LJ. 809, 845

${ }^{207} C f$. id. (discussing use of DNA test in context of proving paternity).

${ }^{208}$ Sex Josh Deutsch, Note, Finders-Kopers: A Bright-Line Rule Awuarting Custody to Gestational Mothars in Cases of Fortiliy Clinic Error, 12 CARDOZO J.L \& GENDER 367, 376-77 (2005); see also L. Lynn Hogue, Azoiding Parentlessmess by Assisted Reproctuctive Tectnology (ART): A Proposal for Enforing Contracts and Avoiding the Public Pobicy Doctrine in Interstate Cases, 4 WHITTIER J. CHIID \& FAM. ADVOC. 269, 276-77 (2005) (discussing case involving mistaken embryo implantation).

${ }^{209}$ See Alice M. Noble-Allgire, Suitchad at the Fotility Chivic: Detemining Matemal Rights When a Child is Bom from Stolen or Mistetiverd Gentic Material, 64 MO. L. REV. 517, 553-54 (1999) (discussing property theory of parental rights).

${ }^{210}$ For example, Carolyn Savage voluntarily turned over the baby to his biological parents when their embryo was mistakenly implanted in her. Canbyn Samage Otio Waman Implonted with Wrong Embrow, Gives Birth, HUFFiNGTON POST (Sept. 26, 2009), http://www.huffingtonpost.com/2009/09/26/carolyn-savage-ohiowoman_n_300710.html. 
gestational surrogate. That knowledge may help the surrogate to make a conscious effort not to become overly attached to the fetus.

Although there are some positive aspects of the genetics test, it also raises some key concerns. For instance, the genetics test may discourage the use of donor eggs or traditional surrogacy arrangements. Some surrogacy arrangements involve donated eggs. ${ }^{211}$ In that instance, neither the contracting woman nor the gestational surrogate is the child's biological mother. Under the reasoning of Belsito, the egg donor would be the child's biological and legal mother. In order to relieve herself of responsibility for the child, the egg donor would have to take legal steps to have her parental rights terminated. Therefore, application of the genetics test may discourage the use of egg donors. On the one hand, the contracting woman may be afraid that the egg donor may assert her rights to the child. On the other hand, the egg donor probably does not want to be held legally responsible for the child. Contrary to public perception, most egg donors are young women who are donating their eggs to receive compensation. ${ }^{212}$ Typically, they are not interested in keeping the resulting children. ${ }^{213}$ Legislatures in some jurisdictions have recognized that fact and have passed statutes stating that an egg donor is never to be considered the legal mother of the child. ${ }^{214}$ In jurisdictions that do not have that safeguard in place, the egg donor may end up recognized as the child's legal mother. In response to this contention, supporters of the Belsito opinion might argue that the egg donor can just take steps to terminate her parental rights. The contracting couple may have to bear the cost of that legal action. As a result, adopting the genetics test has the potential to increase the overall costs of the reproductive process.

The genetics test ignores the fact that the oldest and most common form of surrogacy arrangement involves the use of traditional surrogates. ${ }^{215}$

${ }^{211}$ See Noa Ben-Asher, The Curing Law: On the Evolution of Baby-Making Markets, 30 CARDOZO L. REV. 1885, 1900-01 (2009).

212 See Andrews \& Douglass, supra note 26, at 662-64.

${ }^{213}$ Id. at 664; see Helen M. Alvare, The Case for Regulating Collaborative Reproctuction: A Children's Rights Perspective, 40 HARV. J. ON LEGIS. 1, 13-14 (2003).

214 See, eg., ALA. CODE $\S 26-17-702$ (Westlaw through end of 2010 Reg. Sess.) ("A donor who donates to a licensed physician for use by a married woman is not a parent of a child conceived by means of assisted neproduction. A married couple who, under the supervision of a licensed physician, engage in assisted reproduction through use of donated eggs, sperm, or both, will be treated at law as if they are the sole natural and legal parents of a child conceived thereby."); CONN. GEN. STAT. ANN. $\$ 45 a-775$ (West, Westlaw through the 2010 Feb. Reg. Sess., June Spec. Sess. \& July Spec. Sess.) ("An identified or anonymous donor of sperm or eggs used in A.I.D., or any person claiming by or through such donor, shall not have any right or interest in any child bom as the result of A.I.D.').

215 See Ailis L Burpec, Note, Momma Droma: A Study of How Canada's.National Regulation of Surrogacy Compares to Austratia's Independent State Regulation of Simngacy, 37 GA. J. INT'L \& COMP. L. 305, 308 (2009); see also Suzanne F. 
This is true because the traditional surrogate is usually impregnated by artificial insemination. Artificial insemination is affordable because it can be done without the use of a physician or medical personnel. Gestational surrogacy arrangements involve the use of in vitro fertilization. ${ }^{216}$ Since in vitro fertilization is expensive, gestational surrogacy arrangements are costly. ${ }^{217}$ In a traditional surrogacy situation, since the surrogate supplies the genetic material used to create the child, she would be deemed the legal mother. This might discourage the use of traditional surrogates. The genetics test also disregards the expectations of the parties. Application of the genetics test reduces the surrogate to an incubator or a womb. Some commentators have argued that this is degrading to women.218 Treating the surrogate as if she is nothing more than an incubator ignores the connection the woman develops with the child during the pregnancy. ${ }^{219}$

Living with a person of the same blood may not always be the best arrangement for the child. The news is filled with horror stories of biological parents who have murdered or abused their children.220 Having a blood connection to the child does not guarantee that a woman will be a good mother. ${ }^{221}$ Courts cannot change biological connections. When a woman gives birth to her biological child, the maternal-child relationship is created. Society and the law respect that relationship. Therefore, the courts are reluctant to intervene, and only do so when the child is in danger. ${ }^{222}$ However, courts should not assume that a blood connection is the best way to create a maternal-child relationship. Adjudicating maternity gives courts the opportunity to make sure that the child is not placed in harm's way. Accepting the inveracity that because a woman supplies the genetic material used to conceive the child she should be adjudicated the legal mother may prevent courts from achieving that goal.

Seavello, Are You My Mother?: A Judge's Dexision in In Vitro Fertitzation Stomagary, 3 HASTINGS WOMEN's L.J. 211 , 212 (1992).

${ }_{216}$ See Lisa L. Behm, Legal, Moral $\mathbb{E}$ Intemational Perspectives on Simogate Motherhood. The Call for a Uniform Regulatory Scheme in the United States, 2 DEPAUL J. HEALTH CARE L 557, 558 (1999).

${ }^{217}$ See Keith Alan Byers, Infertity and In Vitro Fertilization: A Growing Need for Consumer-Oriented Regulation of the In Vibro Fertizization Industoy, 18 J. LEGAL MED. 265, 285 (1997).

${ }^{218}$ See, e.g., Antoinette S. Lopez, Privacy and the Regulation of the Technologies: A Decision-Making Approach, 22 FAM. LQ. 173, 192 (1988)

${ }_{219}$ See Nicole M. Healy, Beyond Surngary: Gestational Paranting Agreaments Unda Cabfomia Lav, I UCLA WOMEN's LJ. 89, 121 (1991); see also Anne Goodwin, Determination of Lgal Parentage in Eggs Donation, Embroo Transplontation, and Gestational Sumogacy Amangements, 26 FAM. LQ. 275, 288 (1992).

${ }^{220}$ See Tracy L. Dodds, Note, Defending America's Chaldere: How the Cament System Gets $1 t$ Wrong, 29 HARV.J.L. \& PUB. POL'Y 719, 719 (2006).

221 Ses, eg., Suzanne D'Amico, Comment, Inherently Fanale Cases of Child Abruse and Neglect $A$ Gende-Nadral Anabris, 28 FORDHAM URB. LJ. 855, 855-69 (2001).

${ }_{222}$ Seg eg., Lindsy J. Rohif, Note, The Pyychological-Parent and De Facto-Parant Doctrine How Should the Uniform Parenlage Act Defone "Parent"?, 94 IOWA L. REV. 691, 702 (2009). 


\section{Believing Should Not Make It So}

A surrogate agreement is a contract. Like other types of contracts it is based upon promises between the parties.223 The surrogate promises to gestate and to surrender the baby to the contracting couple. In exchange, the contracting couple promises to pay the surrogate's expenses and abide by other terms of the agreement. ${ }^{224}$ Based upon the terms of the contract, the contracting woman believes that she will be recognized as the mother of the resulting child. Courts applying the intent test attempt to fulfill that belief. The intent test is appropriate because it identifies and tries to carry out the wishes of the parties involved in the process. Application of the intent test is also fair to all of the contracting parties. By carrying out the parties' intent, the court is attempting to make sure they receive the benefit for which they bargained. Hence, the contracting couple is rewarded for taking the steps necessary to insure the child's conception. The couple's intent to parent the child is recognized and honored. Typically, when a surrogate enters into an agreement, she does not intend to be recognized as the child's legal mother. Therefore, the surrogate should not be disappointed if she does not end up with the child. In the absence of a mutual mistake, the parties are getting the benefit of their bargain. The surrogate receives money to cover her expenses, and the contracting couple receives the child they intended to parent.

The intent test is not without problems. Application of the intent test may increase litigation because the court has to decide what the parties intended with regard to maternity. It is always difficult for the court to determine the subjective intent of litigants. The surrogacy contract may not be clear on that issue. Further, the courts may not be able to decide if the intent was informed. In order for informed intent to exist, all of the parties must have understood the ramifications of the intent stated in the contract. ${ }^{225}$ The fact that the parties are in court indicates that one party might not have fully understood the terms of the agreement. Another problem with the intent test is that it may be difficult to apply. The surrogacy process lasts from the implantation of the embryo until the birth of the child. As a result, it may not be easy for the court to decide at what

${ }^{223}$ See Jerald V. Hale, Note, From Baby M to Jaycee B.: Fathas, Mothers, and Children in the Brave Naw World, 24 J. CONTEMP. L 335, 348 (1998).

${ }_{224}$ See Stephen G. York, A Contractual Anabssis of Sirngate Motherhood and a Propased Solution, 24 LOY. L.A. L. REV. 395, 397-98 (1991).

${ }^{225}$ See Jay R. Combs, Comment, Stopping the Baby-Trade: Afforming the Value of Human Life Through the Inxatidation of Strrogacy Contracts: A Bhuprint for Naw Meaico, 29 N.M. L Rev. 407, 412-14 (1999). 
point in the process to evaluate the parties' intent. Prior to the child's conception, the contracting couple probably intends to parent the child. However, once she becomes pregnant, the surrogate may express intent to parent the child. Thus, the court is forced to deal with evolving intents. Each party purports an intention to procreate and raise the child. A party's intent may change after conception, through gestation, and after birth. ${ }^{226}$ If the jurisdiction does not recognize surrogacy contracts, it may be even more difficult for the court to determine the true intentions of the parties with regard to maternity.

The intent test is based upon the mendacity that the beliefs and intentions of the parties should dictate the determination of legal maternity. Blindly enforcing the intentions of the parties is too similar to enforcing contracts to parent or to give up parental rights. Courts have correctly found those types of contracts to be against public policy.227 Carrying out the intent of the parties may not serve the best interests of the child. Relying on the intent of the parties may be acceptable when the source of the contract is an object. Nonetheless, when the subject of the contract is a living, breathing child, carrying out the intent of the parties is inappropriate. In fact, it is dangerous for the court to place undue weight on the parties' intent without considering the best interests of the child. The child does not have an advocate or a voice when it comes to negotiating the terms of the contract. Hence, it is even more important that courts consider the interests of the child when enforcing the contract. A determination of legal maternity results in a permanent classification. Consequently, courts should not make their decisions guided by the falsehood that their sole goal is to give the contracting woman her anticipated outcome.

\section{Bonds Are Meant To Be Broken}

The bond between a mother and a child is not easily broken. That bond starts in the womb. Throughout the three trimesters, the surrogate nurtures and nourishes the child.228 The bond between the woman and child is not broken simply because she gives birth. Courts that have adopted the gestation test for deciding legal maternity assert that the bond between the mother and child should not be ignored. Instead of breaking

\footnotetext{
${ }^{226}$ See Rae, supra note 166 , at $248-49$. 1993).

${ }^{227}$ Ses, eg., T.F. v. B.L, 813 N.E.2d 1244, 1250-51 (Mass. 2004); McKee v. Flynt, 630 So. 2d 44, 50 (Miss.

${ }^{228}$ See Molly J.W. Wilson, Precommitment in Free-Market Procreation: Storogagy, Commissioned Adoption, and Limits on Human Decision Making Capacity, 31 J. LFGIS. 329, 340 (2005); see also Combs, supra note 225, at 414-16.
} 
that bond, some courts use it to justify adjudicating the surrogate as the child's legal mother. Application of the gestation test may be good for the entire surrogacy process. The fear that the gestational surrogate may be deemed the legal mother may cause the contracting couple to think long and hard before selecting a surrogate. This may decrease the likelihood that women who are not emotionally equipped to be surrogates will be chosen to serve as surrogates. Furthermore, the gestation test indicates that courts are sensitive to the fact that a woman who gives birth to a child should not be treated as a stranger to the child.229 The gestational surrogate is the person who cultivates the embryo so that it develops into a child. Consequently, the gestational surrogate's role is critical. The gestation test recognizes the importance of the gestational surrogate's contribution to the child's well-being.

One of the main problems with the gestation test is that it may permit a woman to keep a child that was created using someone else's genetic material. This may encourage a woman to agree to be a surrogate in order to gain a child. In addition, the gestation test negates the importance of genetics. It does not protect the contracting couple from a surrogate who may have suspect motives. It may permit the surrogate to extort money and other benefits from a desperate couple. For example, the surrogate may threaten to seek custody of the child unless she is given additional compensation that is not mentioned in the contract.

Another troubling aspect of the gestation test is the negative impact that it may have on the contracting couple. Application of the test does not weigh the costs to the contracting couple. It appears to focus solely on protecting the interests of the surrogate. The contracting woman has a finite number of viable eggs. ${ }^{230}$ Because of this, the gestational surrogate should not be allowed to keep a child conceived using the infertile woman's genetic or donated eggs. The embryo gestated by the surrogate may be the only one the couple has left. Thus, they would be permanently deprived of the opportunity to become biological parents. ${ }^{231}$ A test that treats the contracting woman as an egg donor is just as demeaning as treating the surrogate as an incubator.

\footnotetext{
${ }^{229}$ See, e.g., Leslie Bender, Genes, Parents, and Assisted Reproductive Technologiex: Arts, Mistakes, Sax, Race, EO Law, 12 COLUM. J. GeNDER \& L 1, 24 (2003).

230 See Kate Lyon, The Egg Came Furst, 47 ORANGE COUNTY LAW. 58, 58 (2005).

${ }^{231}$ See Erica Howand-Potter, Begond Our Conception. A Loak at Cildten Bom Posthomoushy Through Reproductiue Techology and Naw Yonk Intestacy Law, 14 BUFF. WOMEN's LJ. 23, 30-31 (2005).
} 
Advocates of the gestation test ignore the fact that it is based on the untruth that, when it adjudicates maternity, the court should primarily be concerned with protecting the bond between the gestating woman and the child. Separating the child from his or her biological mother may be detrimental to the child. Typically, children have a desire to know the persons who contributed the genetic materials that resulted in their conception. For example, historically, adopted children have often attempted to locate their biological parents. ${ }^{232}$ Similarly, children created as the result of artificial insemination have taken steps to learn the identity of the sperm donors who helped to conceive them. ${ }^{233}$ The contributions of the gestational surrogate are important, but they should not be elevated above the needs of the child.

\section{B. Setting Forth the Truth}

Legal maternity should be adjudicated in a manner that promotes the best interests of the child.

Children do not get to choose their biological mothers. They do not get a voice in the process. However, children are the most affected by maternity determinations. ${ }^{234}$ When a child is conceived naturally, there is nothing courts can do to assure that the child gets the best mother possible. Courts do not get involved in the process unless the woman does something to endanger the child. ${ }^{235}$ Even a woman with a history of child abuse gets the right to parent her child without judicial interference unless evidence exists indicating she is currently abusing or neglecting the child. ${ }^{236}$ Courts have the opportunity to select mothers for children created as the result of surrogacy arrangements. To protect the welfare of the children, courts should make the most of that opportunity. The truth is that maternity should be determined by focusing on the best interests of the child.

The determination of the legal mother impacts the child. Therefore, it is impossible to make that decision without considering the best interests of

232 See, eg., Naomi Cahn \& Jana Singer, Adoption, Identigy, and the Constizution. The Case for Opening Clased Records, 2 U.PA.J. CONST. L 150, 175 (1999).

${ }^{233}$ Seg, eg., Anne R. Schiff, Frustrated Intentions and Binding Biology: Soeking AWD in the Law, 44 DUKE LJ. 524, $564-66$ (1994) (arguing in favor of allowing children bom of artificial insemination to leam identity of sperm donors).

${ }^{234}$ Cf. Hurwitz, supra note 12 , at $129-33$.

${ }^{235} \mathrm{Sec}$ Larkey, supra note 205, at 626-27.

${ }^{236}$ See, eg., Diane I. Bonina \& Ruth A Baha-Jachna, The Treatment of Childten as Chattel in Recont Adoption Decisions, 26 HUM. RTS. 2, 3 (1999); James G. Dwyer, The Child Protection Prdense States' Continued Consignment of Nawbom Babies to Linfit Parents, 93 MINN. L REV. 407, 408 (2008). 
the child. ${ }^{237}$ Since surrogacy agreements are not regulated or heavily scrutinized in most jurisdictions, it is probably even more important to have a neutral third party, like a court, looking out for the best interests of the child. ${ }^{238}$ In custody and visitation hearings, courts have the discretion to appoint a guardian ad litem or other advocate to protect the interests of the child. ${ }^{239}$ That practice is not followed in disputes involving the surrogate and the contracting woman. Thus, the court needs to take extra care to make sure that the child's welfare is protected. The best interests of the child should be the determining factor in most custody cases involving the welfare of children. ${ }^{240} \mathrm{~A}$ review of the treatment of children born as the result of sexual intercourse will illustrate why the best interests of the child standard is the correct one to use to adjudicate maternity.

\section{Sexual Intercourse}

\section{a. The Evolution}

Historically, when making custody determinations, courts were mainly concerned with protecting a man's right to control his lawful children. Thus, in England, custody decisions were made based upon a paternal preference. ${ }^{241}$ The father was entitled to custody of his child regardless of the circumstances. A man was awarded custody of the child even if he literally snatched the baby away from its mother's breast. ${ }^{242}$ The paternal preference was based upon the belief that the woman and the child were the man's property. ${ }^{243}$ The only way the woman could overcome the preference was to prove that the man was a danger to the child. ${ }^{244}$

Initially, American courts adopted this paternal preference and concluded that a man's right to the custody of his children was superior to any other interests. ${ }^{245}$ Even though the courts limited the paternal

${ }^{237}$ Cf. Hurwitz, supra note 12, at 129.

238 See Glenda Labadie-Jackson, The Reprotuctive Rights of Latinas and Cammenial Samngacy Conbracts, 14 TEX. HISP.J.L. \& POL'Y 49, 56-58 (2008).

${ }^{239}$ Sen eg., Rebecca Hinton, Comment, Giving Cuildren a Right To Be Heand: Suggested Reforms To Pravide Louisiona Children a Voice in Crild Custaty Disputes, 65 LA. L REV. 1539, 1544-46 (2005).

240 See Angela R. Russo, Comment, Casts in Crild Custody Actions and the Question of Dischargeability, 2004 U. CHI. Legal. F. 593, 614-16 (2004).

${ }_{241}$ Ser, eg., R v. De Manneville, (1804) 102 Eng. Rep. 1054 (K.B.).

242 Seg, eg., id

${ }^{243}$ See Phyllis T. Bookspan, From a Tender Years Prasomption to a Primay Parent Rrestamption: Has Anytring Really Changed?. . Should It?, 8 BYU J. PUB. L. 75, 78-79 (1993).

${ }^{244}$ Seg eg., Arlene B. Huber, Childten at Rist in the Potities of Crild Custody Strits Acknowledging Their Needs for Nirtore, 32 U. LOUISVIL IE J. FAM. L. 33, 37-39 (1993).

${ }^{245}$ See, e.g., Ullman v. Ullman, 135 N.Y.S. 1080, 1081 (N.Y. App. Div. 1912). 
preference somewhat by considering the best interests of the child, the man's right to retain custody of his children was the prevailing factor in custody disputes. ${ }^{246}$ One could argue that the paternal preference served the best interests of the child because the father usually was the one with the economic resources to provide the best life for the child. The paternal preference in custody cases was slowly replaced by maternal preference in the form of the "tender years" doctrine. ${ }^{247}$

According to the tender-years doctrine, young children should be placed with their mothers because mothers are better equipped to provide them with the nurturing that they need. ${ }^{248}$ Courts applying the tender-years doctrine combined the maternal preference and the best interests of the child standard. In making custody determinations, the courts considered the age of the child to be the primary factor in deciding which placement would promote the child's best interest. ${ }^{249}$ Thus, regardless of the mother's fitness, courts presumed that a young child was best served by remaining in the custody of his or her mother. ${ }^{250}$ The court made decisions about the child's well-being based upon assumptions about the mother-child relationship and not based upon the needs of the specific child before the court.251 The presumption could be overcome by a showing that the mother was indeed unfit. 252

The presumption favoring mothers gave way to the best interests of the child standard. Courts started awarding custody based upon which parent was in the best position to promote the child's interests. ${ }^{253}$ Courts are afforded broad discretion with regard to custody determinations. ${ }^{254}$ The primary goal of the court is to promote the best interests of the child.255 In all American jurisdictions, the best interests of the child standard has been

\footnotetext{
${ }^{246}$ Ses, e.g., id. at $1081-83$.

${ }^{247}$ See Jennifer M. Waterworth, Case Comment, Parent and Child-Gronds for Award of Custody: The North Dakota Supreme Court Recognizes that "Stay-At-Home-Dad" Was Not Discriminated Against Due to His Non-Traditional Role, 75 N.D. L. REv. 391, 395-97 (1999).

${ }^{248}$ Cf. Stephanie N. Barnes, Comment, Strengthening the Father-Child Relationship Through a Joint Custody Presmption, 35 WILJAMETTE L. REv. 601, 605-06 (1999).

${ }^{249} \mathrm{Se}$ Waterworth, supra note 247, at 396.

${ }_{250}$ See Brian J. Melton, Note, Solomon's Wisdom or Solomon's Wisdom Lost: Crild Custady in North Dakota-A Pressemption that foint Custady Is in the Best Interests of the Child in Custody Disputes, 73 N.D. L REV. 263, 268 (1997).

${ }^{251}$ See Marcia O'Kelly, Blessing the Tie that Binds: Preffrence for the Primayy Caretaker as Custadian, 63 N.D. L REV. $481,487-88$ (1987).

${ }^{252}$ Raymon Zapata, Comment, Crild Custody in Texas and the Best Interest Standard: In the Best Interest of Whom?, 6 SCHOLAR 197, 200 (2003).

${ }^{253}$ See Mary K Keamey, The Naw Paradigm in Custody Law: Looking at Parents with a Lowing Eye, 28 ARZ. ST. LJ. 543, 549 (1996).

${ }^{254}$ Ses, eg., Ford v. Ford, 789 A.2d 1104, 1113 (Conn. App. Ct. 2002).

${ }^{255}$ See Miller v. Ark. Dep't of Human Servs., 167 S.W.3d 153, 156 (Ark. Ct. App. 2004).
} 
adopted.256 A majority of states have statutes requiring courts to apply the standard whenever it makes custody decisions impacting a child. ${ }^{257}$ Other states do not have statutes mandating use of the standard. Nonetheless, in those jurisdictions courts have developed a best-interests standard by case law. ${ }^{258}$ Courts make numerous decisions that impact children, including placement and custody determinations, safety and permanency planning, and proceedings for termination of parental rights. When it makes these types of decisions, the court must consider whether its decision will be in the best interests of the child. ${ }^{259}$

\section{b. The Explanation}

There is no uniform definition of the best interests of the child standard. ${ }^{260}$ Thus, it is difficult to explain what courts mean when they refer to the standard. Generally, courts rely on several different factors to determine the best outcome for the child. ${ }^{261}$ The factors focus upon the needs of the child and the capacity to satisfy those needs by the potential caregivers. ${ }^{262}$ The court's paramount concern is the safety and well-being of the child. ${ }^{263}$ Instead of mandating that courts apply certain factors, state statutes typically enumerate guiding principles for courts to consider in making best-interests determinations. ${ }^{264}$ This method gives courts the flexibility to make custody determinations on a case-by-case basis. It also acknowledges that children have unique circumstances and needs. Hence, a bright-line rule that results in a one-size-fits-all approach may not serve the best interests of the child.

Courts have discretion to decide what is in the child's best interests, but that discretion is not absolute. In their statutes, some states and the District of Columbia list specific factors for courts to consider when making

\footnotetext{
256 Carr, supra note 11, at 125; Lauren D. Freeman, The Crild's Best Interests us. the Parent's Free Exarcise of Rebigion, 32 Colum. J.L. \& Soc. Probs. 73, 76 (1998).

257 Seg eg., DEI. CODE ANN. tit. 13, § 722(a) (Westlaw through 77 Laws 2010, chs. 1-475); Cookson v. Cookson, 514 A.2d 323, 328-29 (Conn. 1986); Rachel Sinness, Note, The Best Interests of the Child and the Rights of the Parent: Damron vs. Damron and the Future of Parenting and Child Custody in North Dakota, 84 N.D. L. REV. 999, 1014 (2008).

${ }^{258}$ Seg eg., In re Custody of Kali, 792 N.E.2d 635, 639-40 (Mass. 2003).

259 See Carr, supra note 11 , at 125-27.

260 See Freeman, supra note 256, at 76.

${ }^{261}$ See Shannon J. Kennedy-Sjodin, Note, Keegan v. Gudahl- The Child's Stemame as a Naw Bargaining Chip in the Gane of Divore, 41 S.D. L. REV. 166, 186-87 (1995).

${ }^{262}$ See id; see, eg., Davidson v. Davidson, 576 N.W.2d 779, 785 (Neb. 1988).

${ }^{263}$ See, eg., Shiver v. Shiver, 576 So. 2d 671, 671 (Ala. Civ. App. 1991). 21st Leg).

${ }^{26+}$ Seg, eg., FLA. STAT. ANN. $\$ 39.810$ (West, Westlaw through Ch. 274 (End) of 20102 d Reg. Sess. of the
} 
decisions with regard to the best interests of the child. ${ }^{265}$ The factors that must be evaluated differ from state to state. No one factor is dispositive or is entitled to be given greater weight than any of the others. ${ }^{266}$ Although the language of the statutes varies, legislatures appear to be mainly concerned with those factors that are relevant to the parents' fitness and the child's needs. A survey of court cases indicates that most courts make their decisions by relying on factors that deal with those two concerns. The Price $v$. Price case is a good illustration of the analysis a court undertakes when determining what action is necessary to promote the best interests of the child. ${ }^{267}$

The Price court had to decide which custodial arrangement was best for the child. In its analysis, the court considered the following seven factors: "(1) parental fitness; (2) stability; (3) primary caretaker; (4) child's preference; (5) harmful parental conduct; (6) separation of siblings; and (7) substantial change in circumstances." 268 Only the first six factors are relevant to an initial custody determination. ${ }^{269}$ With regard to parental fitness, the court attempted to ascertain which parent could provide the child with the best care. ${ }^{270}$ In making that determination, the court evaluated the physical and mental health of each parent. ${ }^{271}$ The court also evaluated their approach to parenting. ${ }^{272}$ In order to evaluate the stability of each parental home, the court examined the nature of the parental and nonparental relationships the child had established. ${ }^{273}$ Further, the court looked at the level of contact the child had with the external communities where his parents resided. ${ }^{274}$

${ }^{265}$ Ses eg., 705 IL. COMP. STAT. ANN. 405/1-3(4.05) (West, Westlaw through PA. 96-1402 of the 2010 Reg. Sess.); KY. REV. STAT. ANN. § 620.023 (West, Westlaw through end of 2010 legis); MD. CODE ANN., FAM. LAW § 5-525(f)(1) (West, Westlaw through all chs. of the 2010 Reg. Sess. of the Gen. Assem., effective through Oct 1,2010$)$.

${ }_{266}$ Seg, eg., In re Pfeuffer, 837 A.2d 311, 314 (N.H. 2003).

267 Price v. Price, 611 N.W.2d 425, 430-36(S.D. 2000).

268 Id. at 430.

${ }^{269}$ Seg eg., id at 436 (applying "substantial change of circumstances" in context of changing custody).

270 See id. at 430 .

271 See id at 430-32.

272 Sex id. In particular, the court analyzed the following factors relating to parental fitness:

(1) mental and physical health; (2) capacity and disposition to provide the child with protection, food, clothing, medical care, and other basic needs; (3) ability to give the child love, affection, guidance, education and to impart the family's religion or creed; (4) willingness to maturely encourage and provide frequent and meaningful contact between the child and the other parent; (5) commitment to prepare the child for responsible adulthood, as well as to insure that the child experiences a fulfilling childhood; and (6) exemplary modeling so that the child witnesses firsthand what it means to be a good parent, a loving spouse, and a responsible citizen.

Id. at 430 (quoting Fuerstenberg v. Fuerstenberg, 591 N.W.2d 798, 807 (N.D. 1999)).

273 Id at 432.

274 Se id. The court evaluated stability by emphasizing the following factors:

(1) the relationship and interaction of the child with the parents, step-parents, siblings and extended 
The court concluded that the primary caretaker was the person who had spent the most time parenting the child prior to the hearing. ${ }^{275}$ The primary caretaker could also be the person who would be able to spend the most time with the child after the custody determination. ${ }^{276}$ The court gave this person a slight advantage. The child's age and maturity was also a factor. ${ }^{277}$ If the court determined that the child was sufficiently old and mature enough, the court would give weight to the child's preference. ${ }^{278}$ The harmful-parental-conduct factor only comes into play when the parent acts in a way that negatively impacts the child's physical and/or emotional well-being. ${ }^{279}$ The court's decision was also influenced by a desire to keep siblings together. ${ }^{280}$ After considering all of these factors, the court held that a change in custody was not in the child's best interests. ${ }^{281}$ Courts use different factors to determine the appropriate custodial arrangement for the child. Nonetheless, they all focus upon evaluating the fitness of the parents and the needs of the child involved in the case.

\section{Surrogacy}

As it currently exists, the best interests of the child standard is applied predominately to preexisting parental arrangements. It is not used to make initial parentage determinations. In situations involving children conceived by sexual intercourse, it is understandable that courts should not become involved in adjudicating the parentage of every child born in the country. That would be judicially infeasible and probably unconstitutional. Giving courts the discretion to apply the best interests of the child standard to initial parentage decisions would unduly interfere with the right to privacy and the parental right to the care, custody, and control of their children.282 However, surrogacy situations are different. In cases involving children

families; (2) the child's adjustment to home, school and community; (3) the parent with whom the child has formed a closer attachment, as attachment between parent and child is an important developmental phenomena and breaking a healthy attachment can cause detriment; and (4) continuity, because when a child has been in one custodial setting for a long time pursuant to court order or by agreement, a court ought to be reluctant to make a change if only a theoretical or slight advantage for the child might be gained.

Id. (quoting Fuerstenberg, 59l N.W.2d at 808).

275 Id at 433-34.

276 Id at 433 ("The primary caretaker can be identified by determining which parent invested predominant time, care and consistency in raising the child."' (quoting Fiverstenberg, 591 N.W.2d at 808)).

277 Id at 434.

278 Sex id.

279 See id. at 435.

280 See id at $435-36$.

281 Id at 436.

${ }^{282}$ Cf. Solangel Maldonado, When Fathe (or Mother) Doesn't Know Best Quasi-Parents and Parental Deference After Troxed v. Granville, 88 IOWA L REV. 865, 895 (2003). 
conceived as a result of surrogacy agreements, the dispute is usually not about custody; it's about parentage. We live in a society of laws; therefore, people should be discouraged from settling their own disputes. By the time the case comes to court, the relationship between the surrogate and the contracting persons has usually deteriorated. Thus, the odds of a peaceful resolution of the matter are slim. Hence, the court must intervene to keep the peace and to protect the child. Thus, using the best interests of the child standard to make initial parentage decisions in surrogacy situations may be acceptable.

\section{a. Arguing for the "Best Interests of the Child" Test}

Fohnson v. Calvert (Dissenting Opinion) $)^{283}$

The dissent in the fohnson case correctly concluded that the appropriate test for determining the legal mother of the child is the best interests of the child standard. ${ }^{284}$ According to the dissent, the gestational mother and the genetic mother were both the child's natural mothers, so both had an equal claim to the child. ${ }^{285}$ Nonetheless, since the state only permitted one woman to be classified as the child's legal mother, the court had to decide which woman was entitled to wear that label. ${ }^{286}$ After reviewing the facts and applicable law, the dissent opined that the legal issue was which factor should be the tie-breaker when determining whether to designate the surrogate or the contracting woman as the child's legal mother. ${ }^{287}$ The dissent maintained that the standard should be the "best interests of the child" because that standard would enable the court to reach the decision that was most protective of the child's welfare. ${ }^{288}$ In addition, the dissent contended that the intent test was too inflexible to serve the child's best interests. ${ }^{289}$ The dissent concluded that the court should evaluate the households and lifestyles of both mothers to determine which placement would be in the child's best interests. ${ }^{290}$ The dissent ultimately proposed

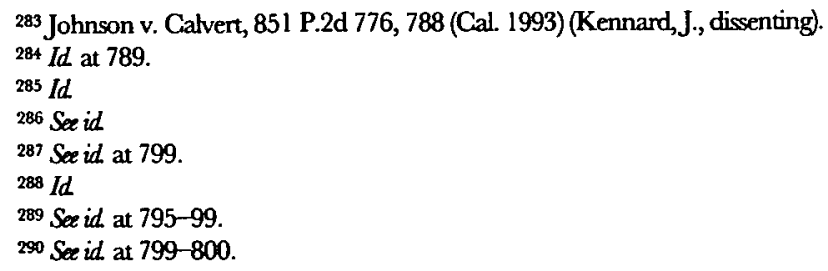


that courts determine maternity on a case-by-case basis relying on the best interests of the child standard. ${ }^{291}$

Applying the best interests of the child standard to determine maternity is a good idea because it is consistent with the standard the court uses to determine custody, visitations, and other issues with regard to children. ${ }^{292}$ Also, the best interests of the child standard gives the courts flexibility. That flexibility is important because different factual situations may lead to different outcomes. ${ }^{293}$ The child is the one person involved in the transaction that does not have a voice, so the court's primary concern should be ensuring that the child's interests are protected.

As currently applied, the best interests of the child test has its weaknesses because it focuses too much on the fitness of the women. The application of the best interests of the child standard may encourage litigation. If the surrogate changes her mind and decides that she wants to keep the child, she knows that, if she can prove that she is in the best position to care for the child, she has a chance of winning custody of the child. Another concern is that the traditional best interests of the child standard is too subjective. ${ }^{294}$ Judges may be influenced by their own culture and beliefs when deciding which woman would make the better mother. ${ }^{295}$ As a result, judicial biases may disadvantage one woman. For instance, courts may favor the contracting couple over the single surrogate. Further, traditional couples may be favored over nontraditional couples. ${ }^{296}$ Most surrogates are women with modest means. ${ }^{297}$ Thus, they may be disadvantaged if the courts focus on which woman can provide the child with the most financial resources.

A further weakness of the best interests of the child standard presently being applied is that it may result in an outcome that is contrary to the parties' intentions. Courts will be forced to decide how to break the tie when both women are fit to care for the child. The best interests of the child test ignores the expectations of the parties. In some instances, the best

291 See id. at 800.

${ }^{292}$ See, eg., sources cited supra note 257.

${ }^{293}$ See Rachel M. Colancecco, Note, A Flexible Solution to a Krotty Problem. The Best Interests of the Child Standard in Relocation Disputes, 1 DREXEL L REV. 573, 607 (2009); see also T.B. v. L.R.M., 753 A.2d 873, 888 (Pa. Super. Ct. 2000) ("The 'best interest of the child' standard considers all factors that legitimately have an influence upon the child's physical, intellectual, moral and spiritual well being on a case-by-case basis.").

294 See Gilliam, supra note 12 , at 530.

295 Ser id.

296 See id.

${ }^{297}$ See Andrews \& Douglass, supra note 26, at 673-74 (providing demographics of surrogates); Barbara L. Atwell, Stongacy and Adoption: A Case of Incompatibitity, 20 COLUM. HUM. RTS. L REV. 1, 43 (1988). 
interests of the child test may result in the surrogate being unjustly enriched if she is adjudicated as the best person to parent the child. ${ }^{298}$

The best interests of the child standard is not used to adjudicate maternity in cases involving children conceived by sexual intercourse. In those instances, the test typically comes into play when the court has to decide whether to terminate the woman's maternal rights. It is as if the law gives a woman who conceives naturally the benefit of the doubt and presumes that she retains her maternal rights until something occurs to rebut the presumption that she is a good mother. The application of the best interests of the child test to determine maternity in a surrogacy situation results in both women having to prove that they are fit to parent the child before anything happens to put that fact in dispute. The shortcomings of the best interests of the child standard are outweighed by the usefulness of the standard. If it is adapted to meet the unique needs of a child conceived as the result of surrogacy agreements, the best interests of the child standard is the one courts should use to adjudicate maternity.

\section{b. Applying the "Best Interests of the Child" Test}

The best interests of the child standard encompasses two main components: protection of the physical and psychological well-being of the child and fairness to the women involved in the process. When adjudicating maternity, courts should strive to place the child in a home where his or her needs will be met. Courts should also seek to insure that the outcome is fair to the women involved in the process. Nevertheless, the primary goal of the courts should be to promote the best interests of the child. The best interests of the child standard should be adapted to apply to surrogacy situations that require an adjudication of maternity. Generally, courts apply the standard in cases involving issues of custody, visitation, and termination of parental rights. In surrogacy cases, the women are asking to be adjudicated the legal mother of the child. This is similar to a request for custody.

As indicated earlier, a key consideration in custody cases is parental fitness. ${ }^{299}$ All things being equal, the parent that is most fit is usually awarded custody. In a custody case, an evaluation of parental fitness indicates that the person has a track record that the court can review.

\footnotetext{
${ }^{298}$ Se John M Suender, Comment, Simagate Motherhood Agreaments and the Law in Pennsyturaria, 91 DiCK. L. REV. 1085, 1107 (1987).

${ }^{299}$ See supra text accompanying notes 270-72; se also Richand F. Storrow, The Bioethics of Arospective Parenthood In Pusrat of the Proper Standord for Gatekeoping in Infertility Clinics, 28 CARDOZO L REV. 2283, 2304 (2007).
} 
When a court has to make an initial parentage determination, it is often difficult to evaluate parental fitness. Custody determinations are usually made after the child has been living with one or both of the parties for a period of time. In addition, custody disputes usually involve a man and a woman battling for physical custody of the child. ${ }^{300}$ In those types of cases, it makes sense for the courts to consider factors like parenting skills and the emotional ties between the parent and the child. When adjudicating maternity, courts are typically unable to obtain evidence relevant to those factors. The contracting couple is often childless, so it is difficult to determine whether or not they will be good parents. The surrogate may or may not already have children that she conceived through sexual intercourse. At the time most maternity actions are brought before the court, the child usually is not emotionally attached to either woman.

The surrogacy situation is different enough from the custody dispute to justify modifying the best interests of the child standard. Courts should take a needs-based approach as opposed to a parental-rights approach. A needsbased approach emphasizes the needs of the child. To the contrary, a parental-rights approach focuses upon the rights of the parents. Parents have the right to custody of their children unless they are shown to be unfit. ${ }^{301}$ The correct test to adjudicate legal maternity is a best interests of the child test that evaluates parental potential, environmental stability, and primary-caretaker status.

\section{i. Parental Potential}

In custody cases, courts evaluate the fitness of the persons seeking custody. This is not the appropriate approach for maternity adjudication cases. The focus should be on the needs of the child. The woman who has the best potential to provide for the child's needs should be adjudicated the legal mother. In order to assess parental potential, courts should consider the following factors for each woman: (1) the emotional and physical health; (2) the financial resources available; and (3) the support system in place. The emotional health of the woman is important because the mother's mental condition will impact the child's emotional development. Moreover, a woman who is emotionally unstable may physically harm or fail to protect

\footnotetext{
300 Ses, eg., Jerry A Behnke, Note, Pauns or People? Protecting the Best Interests of Children in Interstate Custody Disputes, 28 LOY. LA. L. REv. 699, 702 (1995) (discussing history of custody disputes between natural parents and best-interests test).

${ }^{301}$ See Storrow, sepra note 299, at 2303.
} 
the child from harm. ${ }^{302}$ The woman's physical health is relevant because an unhealthy woman will have a difficult time caring for the child. This is especially critical if the woman will be the child's only parent. It is crucial that the woman has enough financial resources to provide the child with adequate food, clothing, and shelter. Due to the circumstances of his or her birth, the child born as a result of a surrogacy arrangement may need more family support than a child born by other means. This family support can come in the form of extended family or friends.

\section{ii. Stability}

Courts should also evaluate the women's ability to provide a stable environment for the child. ${ }^{303}$ To make that determination, courts should take into account the employment history of the women, the length of time the women have been in their homes, and the relationship between the women and their husbands or significant others. A woman's work history is relevant to determining whether or not she is economically stable. Economic stability is essential because children born into poverty face numerous challenges. ${ }^{304}$ The length of time a woman has been in her home impacts the child's ability to receive a good education and to form a social network. Both of those things are necessary for a child to have a successful life. Children are profoundly affected by the interactions between the adults in their lives, especially their parents. Children with two adult caretakers tend to have better outcomes than those raised in single-parent homes. ${ }^{305}$

\section{iii. Primary Caretaker}

Finally, courts should designate one of the women as the primary caretaker of the child. The primary caretaker should be given preference with regard to custody. ${ }^{306}$ The woman who has invested the most time in caring for the child should be named the primary caretaker. When

\footnotetext{
${ }^{302}$ Seg, eg., In re R.B., II, 674 N.W.2d 685, 685 (Iowa Ct. App. 2003).

303 Ser Claudio DeBellis \& Marta B. Soja, Note, Gregory K. Child Standing in Parental Temanation Proceatings and the Implications of the Faster Parent-Faster Crild Relationstiph on the Best Interests Standand, 8 ST. JOHN'S J. LEGAL COMMENT. 501, 519 (1993).

${ }^{304}$ Seg eg., Virginia S. Radding, Intention v. Implementation: Are Many Children, Removed from Their Biological Famities, Being Protected or Deprived, 6 U.C. DAVIS J.JUV. L. \& POLY 29, 41-42 (2001).

${ }^{305} \mathrm{Seg}$ eg. W. Bradford Wilcox \& Kobin F. Wilson, Bringing Up Baby: Adoption, Marrigge, and the Best Interests of the Crild, 14 WM. \& MARY BILL RTS.J. 883, 891-94 (2006).

${ }^{306}$ Ses eg., Gary Crippen, Stombing Begond Best Interests of the Child: Rexamining Child Custaty Standerd-Setting in the Wake of Minnesota's Four Yaur Experiment with the Prinury Caretake Preforence, 75 MINN. L. REV. 427, 434-37 (1990); Pamela Laufer-Ukeles, Selective Rexogrition of Genda Difference in the Lav: Ravating the Caretater Role, 31 HARV.J.L. \& GENDER 1, 47 (2008).
} 
determining the amount of time that the women have invested in the child, courts should look at all of the circumstances surrounding the child's conception and birth. Courts should contemplate the amount of effort the women exerted to ensure the child's conception and birth. The contracting woman's efforts to have the child conceived should be acknowledged. If the case involves a traditional surrogate, the contracting woman should be credited for arranging for the surrogate's eggs to be fertilized with the sperm obtained by the contracting woman. In a gestational surrogacy situation, the contracting woman's contribution of genetic material to make the child's conception possible should weigh in favor of finding her to be the primary caretaker.

Courts should also examine the surrogate's pre-conception role. A traditional surrogate supplies genetic material and her womb to enable the child to be conceived. ${ }^{307}$ The gestational surrogate also plays an important part in the child's conception. In addition to providing the womb, the gestational surrogate takes certain medicines to prepare her body for the surrogacy. ${ }^{308}$

After the child is conceived, the surrogate is responsible for protecting the fetus, so that the child can be born healthy. The contracting woman's role is limited post-conception. Nonetheless, she does make some contributions such as attending the prenatal appointments and paying for the medical expenses. By going through labor, the surrogate takes the steps that are necessary to ensure that the child is born. Although she does not make a physical contribution during that stage of the process, the contracting woman makes an emotional investment in the child's wellbeing. Prior to assigning the role of primary caretaker, courts should take into account the part that the surrogate and the contracting woman played in the conception and birth of the child.

\section{iv. Fairness}

A valid criticism of the best interests of the child standard is that it is too subjective. That subjectivity permits judges to make custody decisions based on their own biases. In order to be fair to all of the parties, the legislatures should authorize the creation of surrogacy review boards. Currently, several jurisdictions have statutes setting forth the requirements

307 See Watson, supra note 29 , at 529.

${ }^{308}$ See Flavia Berys, Intopreting a Rent-A-Wamb Contract How Califomia Couts Should Proceed When Gestational Sumgacy Amangements Go Sour, 42 CAL. W. L. REV. 321, 330 (2006) (discussing necessity for gestational surrogate to go through hormonal stimulation for egg retrieval). 
that gestational surrogacy agreements must meet to be valid. ${ }^{309}$ Moreover, in some states, surrogacy agreements must be court approved in order to be enforceable. ${ }^{310}$ Consequently, permitting surrogacy review boards to make recommendations with regard to maternity would not be overly intrusive. The boards would be made up of independent experts. Currently, courts are forced to listen to competing experts hired by the parties. ${ }^{311}$ These experts are being paid to advocate for the positions of the persons who hire them. Hence, they may not be concerned with promoting the best interests of the child. Even a court-appointed guardian ad litem may not be completely impartial. The surrogacy review boards would consider all of the relevant facts of a case through a best interests of the child lens and make recommendations to the court. The recommendations would not be binding, but they would give guidance to the courts.

\section{CONCLUSION}

The advances in reproductive technology have given women more reproductive choices. Women are able to rewind their biological clocks and become mothers later in life. If a woman is unable to carry a child, she may be able to utilize the services of a surrogate to become a mother. The amount of assistance the woman receives from the surrogate depends upon the state of her reproductive health. A woman who is no longer capable of producing eggs can arrange for a traditional surrogate to supply the eggs and to carry the child to term. Gestational surrogacy is an option for the woman who cannot carry the embryo made from her genetic material. Surrogacy is a great way to create a family.

If medicine is the hare, the law is the tortoise. As long as the surrogate honors the contract and surrenders custody of the child to the contracting woman, everything goes smoothly. However, when faced with custody disputes involving surrogates and contracting women, courts are not sure how to react. For courts, the resolution of traditional custody disputes is easy because the law is well-settled. In surrogacy dispute cases, since two women are seeking to be declared the legal mother of the child, instead of deciding custody, courts have to adjudicate maternity. As a consequence of the lack of clear legislative guidance and bright-line rules, courts have relied

\footnotetext{
Sess.).

${ }^{309}$ Seg eg., 750 ILL. COMP. STAT. ANN. 47/25 (West, Westlaw through P.A. 96-1402 of the 2010 Reg.

${ }^{310}$ Seg, eg., VA. CODE ANN. \$ 20-160 (West, Westlaw through end of 2010 Reg. Sess.).

311 Ses eg., Laura Sack, Women and Children First A Foninist Anabysis of the Arimary Caretater Standard in Child Custody Cases, 4 YALEJ.L. \& FEMINISM 291, 297 (1992).
} 
upon several different theories to decide whether the surrogate or the contracting woman should be declared the legal mother of the child. The underlying premise of three of those theories is the lie that the standard for determining maternity should be the actions of the women. The final theory is based upon the truth that the test for adjudicating maternity should focus on the needs of the child.

In situations involving children born as the result of sexual intercourse, the common law rule is that the woman who gives birth to the child is the child's legal mother. Since the woman who gives birth is also the woman who supplies the genetic material to conceive the child, the rule is relatively easy to implement. Things become more complicated when one woman gives birth to a child conceived using the genetic material of another woman. In those cases, some states follow the common law fallacy and conclude that, since she gives birth to the child, the surrogate should be recognized as the child's legal mother. This approach is referred to as the gestational theory of maternity. Other courts believe the lie that the sole indicator of maternity should be genetics. Thus, the woman who supplied the genetic material used to create the child should be designated as the child's legal mother. California and other jurisdictions have embraced the untruth that maternity should be determined by relying on the intent of the parties. Therefore, the woman who signed the contract intending to parent the child should be deemed to be the child's legal mother.

The court that decided the Baby $M$ case used the best interests of the child standard to award custody of the child. At least one judge has realized the truth. He argued that this same standard should be used to determine whether the surrogate or the contracting woman should be recognized as the child's legal mother. For decades, courts have relied upon the best interests of the child standard to make decisions that impact children. Nonetheless, the standard has not been used to make initial parentage determinations. Although the standard has been around for a long time, it is still not well-developed. Neither the legislatures nor the courts have put forth a clear definition of what the "best interests of the child" means. Courts evaluate various factors to decide which outcome will promote the child's best interests.

The correct standard for adjudicating maternity is a modified version of the best interests of the child standard. Courts should not apply the standard to maternity adjudication cases in the same manner that they apply them in custody cases. In order to choose the maternal arrangement that will promote the child's best interests, courts should consider the parental potential of each woman, the stability of each woman, and the 
investment that each woman made to ensure the child's conception and birth. In the interest of fairness, courts should seek guidance from an independent board of experts. 